\title{
İSLAM HUKUKU AÇISINDAN KOOPERATIFLERIN HUKUKİ NİTELİĞİ
}

\author{
Dr. Öğr. Üyesi Aytaç AYDIN ${ }^{* *}$
}

\begin{abstract}
ÖZET
Ülkemizde kooperatifler önceleri "teşekkül” olarak adlandırılmış daha sonra “ortaklık” ve son olarak 6102 sayılı Kanunla "ticaret şirketleri” arasında sayılmıştır. Ancak geçmişten günümüze hukukçular bu tanımlamaların kooperatifin hukuki niteliğini yeterince ifade etmediğini belirtmişler ve bu tartışmalar Yargıtay kararlarına da yansımıştır. Günümüz hukukunda kendine has özellikleri olan tüzel kişiliği haiz sosyo-ekonomik "birlik" olarak tanımlanmasına dair görüşler ağırlık kazanmıştır.

İslam hukuku açısından kooperatifler konusu ağırlıklı olarak “sigorta kooperatifleri” kapsamında tartışılmıştır. Bu kapsamda teberru ve yardımlaşma esasına dayalı sigortalar caiz olarak değerlendirilirken ticari sigortalar bazı İslam hukukçuları tarafından caiz görülmemiştir.

Ülkemizde sigorta kooperatifleri dışında yirmiden fazla kooperatif şirketi çeşidi vardır. Zaman zaman bu şirketlerin İslam hukuku açısından uygunluğuna ve kooperatiflerin tamamını kuşatıcı şekilde "İslam hukuku açısından kooperatiflerin hukuki niteliğì"ne dair sorular gelmektedir. Bu konudaki sorulara cevap olması ve bu alandaki boşluğu doldurması amacıyla bu çalışmaya ihtiyaç duyulmuştur.

Konumuzla ilgili Kanun, tüzük ve yönetmelikler taranarak "ortaklıklar ve kooperatif hukuku” ile ilgili hem güncel hukuk literatüründen hem de klasik ve çağdaş İslam hukuk literatüründen istifade edilmiştir. Ayrıca, kanun ile ilgisi çerçevesinde AAOIFI (The Accounting and Auditing Organization for Islamic Financial Institutions Shari'ah Standards) standartları da taranarak konu tahlil edilmiştir.

Çalışmamızda, İslam hukukunda kooperatifler isimsiz akitler kapsamında, akit şirketleri içinde değerlendirilmiş olup, kendine has özeliği olan yeni bir ticari şirket çeşidi olarak nitelendirilmiştir. Kooperatif şirketi anasözleşme ve işlemlerinde "garar”, "riba”, “cehâlet”, "kumar” gibi özellikleri taşımayacak şekilde kurgulanarak İslam akit teorisi kapsamındaki sabit ilke, hüküm ve değerlerle örtüşmesinin zorunluluğu ortaya konulmuştur.
\end{abstract}

Anahtar Kelimeler: Kooperatiflerin Hukuki Niteliği, İslam Hukuku, Sigorta Kooperatifleri, Tekâfül, İslamî Sigorta.

DOI:10.33432/ybuhukuk.809409 -Geliş Tarihi: 12.10.2020 - Kabul Tarihi: 21.12.2020.

* Ankara Yıldırım Beyazıt Üniversitesi, İslami İlimler Fakültesi, İslam Hukuku Anabilim Dalı, ofisaytac@hotmail.com, ORCID:0000-0001-9016-5711. 


\title{
LEGAL CHARACTERISTIC OF COOPERATIVES IN TERMS OF ISLAMIC LAW
}

\begin{abstract}
In our country, cooperatives were initially defined as "establishment" and later named as "partnership" and finally they were expressed among "commercial companies" with the law numbered 6102. However, from past to present, lawyers have stated that these definitions don't adequately express the legal characteristic of the cooperative and these discussions were reflected in the decisions of the Supreme Court. In today's secular law, opinions about defining it as a socio-economic "union" with a legal personality that has its own characteristics have prevailed.

In terms of Islamic law, the issue of cooperatives has been mainly discussed within the scope of "insurance cooperatives". In this context, insurances based on grant and solidarity were deemed permissible, but some Islamic lawyers did not consider commercial insurance permissible.

In our country, there are more than twenty types of cooperative companies other than insurance cooperatives. Sometimes questions arise regarding the suitability of these companies in terms of Islamic law and the "legal character of cooperatives in terms of Islamic law" which encompasses all cooperatives. This study was needed to answer questions on this subject and to fill the gap in this area.

Laws, rules and regulations related to this topic were examined; both the current legal literature on "corporations law and legislation" and classical and contemporary Islamic legal literature were used. In addition, the subject was analyzed by scanning AAOIFI (The Accounting and Auditing Organization for Islamic Financial Institutions Shari'ah Standards) standards within the framework of its relevance to the subject.

In our studies on cooperatives in Islamic law; it is appropriate to define it as a new type of commercial company with its own characteristics, which we can consider among contracting companies within the scope of anonymous contracts. The cooperatives should be constructed in such a way that it does not have the characteristics of "uncertainty" (garar), "interest" (ribâ), "ignorance" (cehâlet) and "gambling" (kumar) in the regulations of these associations. In addition, it should coincide with the fixed principles, decrees and values within the scope of Islamic contract theory.
\end{abstract}

Keywords: Legal Character of the Cooperatives, Islamic Law, Insurance Cooperatives, Takâful, Islamic Insurance. 


\section{Gİiş}

Bir ülkenin maddi ve manevi kalkınmasında, ülke halkının çeşitli meslek örgütleri etrafında birleşmesi, bireylerinin de buna paralel olarak kurulan mesleki örgütlerde organizatör ve katılımcı olarak yer alması önemli bir yeri haizdir. Bu örgütler kapsamında değerlendirebileceğimiz kooperatifler de kâr amacı gütmeyen kuruluşlar olarak ekonomik faaliyetlerini devam ettiren, özel yapıya sahip ekonomik ve sosyal amaçlı kuruluşlardır. Bu özellikleri sebebiyle kooperatifler, dünyadaki benzer kuruluşlarda olduğu gibi belirli muafiyetlerden ve istisnalardan faydalanma hakkına sahiptir.

Günümüze oranla geçmişte pazarlama kanallarını üretici ve tüketici lehine neticelenecek şekilde düzenleyen organizasyonlara pek ihtiyaç hissedilmiyordu. Ancak günümüzde pazar ekonomisinin de etkisi ile bu ihtiyaç daha derinden hissedilmektedir. Kooperatifler de bu ihtiyacın bir uzantısı olarak kurulmuş; yardımlaşmayı, dayanışmayı ve üretici ile tüketicinin ekonomik kazancını teminat altına almayı amaçlayan kuruluşlar olarak görülebilir.

İslam toplumunun kuruluş yıllarına gittiğimizde; Hz. Peygamber (sav) döneminde günümüze kıyasla çok daha sade olan pazar yapısında üretici ve tüketicinin korunması amacına hizmet edecek şekilde ilkelerin konulduğunu görmekteyiz. Mesela, üreticinin ürününü pazara sunamadan pazar kapısında karşılanıp tüketiciye malını arz-talep çerçevesinde oluşacak fiyata göre sunmasına mani olan, köyden veya dışarıdan şehre ihtiyaç maddelerini getirenlerin yolda karşılanması (telâkkı'r-rukbân) yasaklanmıştır. ${ }^{1} \mathrm{Bu}$ uygulamayı, fiyatların pazardaki arz-talep şartlarına göre adaletli bir şekilde oluşmasına zemin hazırlayan, tüketici ile üretici lehine neticelenecek düzenlemeler kapsamında yorumlamak mümkündür. Tüketici malı daha pahalıya satın almamış ve üretici de piyasada oluşan fiyattan daha düşük fiyata satmak zorunda kalmamış olmaktadır. ${ }^{2}$ Dolayısı ile hem tüketici hem de

Buhârî, Ebu Abdillah Muhammed b. İsmail (1992) el-Câmiu's-Sahîh, İstanbul, Çağrı, Buyû', 72.

2 Kallek, Cengiz (2000) “İhtikâr”, Türkiye Diyanet Vakfı İslam Ansiklopedisi, C: 21, s. 561. 
üretici korunmuş olmaktadır. Bugün üretim ve tüketim ile ilgili kooperatiflerin de benzer bir amacı gerçekleştirdikleri düşünülebilir.

Kooperatifler ülkemizde Cumhuriyet dönemi ve öncesinde kullanım alanı bulmuş, ancak tüzel kişiliklerinin hangi kapsamda değerlendirileceği birçok tartışmanın konusu olmuştur. İslam hukukunda klasik sözleşmeler ve şirketler arasında yer almayan bu oluşum, zamanla pozitif hukukta yerini almış ve toplum ihtiyaçlarına göre şekillenerek belirli sosyal ihtiyaçları da karşllayacak şekilde gelişimini sürdürmüştür. Önceleri “teşekkül” olarak ${ }^{3}$ adlandırılan kooperatif daha sonra "ortaklık" ve son olarak günümüzde ticaret şirketleri arasında sayılmış olmakla beraber hukuki niteliği ile ilgili tartışmalar ${ }^{6}$ sosyal yönünü de merkeze alarak devam etmiş ve Yargıtay kararlarına da yansımıştır. ${ }^{7}$ Ancak, kooperatiflerle ilgili yapılan son düzenlemeler incelendiğinde ticari şirketler arasında sayılması mevcut işleyişi ile örtüşen en sağlıklı nitelendirme olarak görülebilir.

İslam hukukunda ise ilgili tartışmalar 19. yüzyıldan sonra "sigorta" ile başlayıp kooperatif şirketlerinin bir çeşidi olan sigorta kooperatifleri ile günümüze kadar devam etmiştir. İslam âleminde "Tekâfül”, "İslâmî sigorta", "et-Te’mînu't-Teâvunî" adıyla bilinen bu sigorta ülkemizde "katılım sigortacılı̆̆ı” adı ile uygulama alanı bulmuştur. ${ }^{8}$ Ancak ülkemizde sigorta

3 Kooperatifler Kanunu (Koop.K), Resmî Gazete 13195 (10 Mayıs 1969), Kanun No: 1163, $<$ https://www.mevzuat.gov.tr/mevzuat?MevzuatNo=1163\&MevzuatTur=1\&MevzuatTertip $=5>$ s.e.t 20.07 .2020 .

4 Kooperatifler Kanununda Değişiklik Yapılması Hakkında Kanun (Koop.KDK) Resmî Gazete 25455 (7 Mayis 2004), Kanun No: 5146, <https://www.resmigazete. gov.tr/eskiler/2004/05/20040507.htm\#1> s.e.t 20.07.2020.

5 Türk Ticaret Kanunu (TTK), Resmî Gazete 27846 (14 Şubat 2011), Kanun No: 6102.

6 Şener, Oruç Hami (2019) Teorik ve Uygulamalı Ortaklar Hukuku, Ankara, Seçkin, s. 108109.

7 Mollaoğlu, Yusuf (2018) “Kooperatiflerin Hukuki Niteliği”, (Yüksek Lisans), Selçuk Üniversitesi, Sosyal Bilimler Enstitüsü, s. 39, 55, 92-138.

8 Sigortanın İslam hukukuna uyun olup olmadığına dair ulaşabildiğimiz ilk fikhi değerlendirmeler 1820'lerden sonra İbn Âbidin'e aittir. Daha sonraları sigorta konusunun derinlemesine araştırılıp akademik çevrelerde tartışma ortamlarına taşınması 1960'larden sonrasına rastlamaktadır. 1961 yılında Mısır'da M. Ahmed ez-Zerka'nın sunduğu "İslâm Hukuku Zaviyesinden Sigorta" adlı tebliğ ile başlayarak çok sayıda sempozyum ve 
kooperatifi haricinde yirmiden fazla kooperatif şirketi çeşidi mevcuttur ve kendine özel kanunu olanlar dışındakilerin muameleleri Kooperatifler Kanunu'na göre yürütülmektedirler. Kooperatifler Kanunu kapsamında kooperatif çeşitlerinin tümünü kapsayacak şekilde "İslam hukuku açısından kooperatiflerin hukuki niteliğì”ni inceleyen bir çalışmaya rastlanmamıştır. Çalışmamızın amacı, Uluslararası Kooperatifler Birliği tarafından kabul edilen kooperatif ilkeleri ve 1163 sayılı Kooperatifler Kanunu'nu esas alarak İslam hukuku açısından kooperatiflerin hukuki niteliğini tespit etmeye çalışmaktır.

\section{KOOPERATİFÇİLİĞİ TARİHİ ARKA PLANI}

Kooperatifçiliğin ana karakterinde yer alan unsurları yardımlaşma, dayanışma, ortak hareket etme, toplum sorunlarına çözüm bulma esas alındığında kooperatifçilik tarihinin insanlık tarihi ile başladığı ifade edilebilir. Ancak günümüzdeki anlamda kooperatifçiliğin kuruluşu çok daha yenidir. 1752 yılında Amerika'da şehir yangınına karşı yardımlaşma amaçlı kurulan Philadelphia Sigorta Kooperatifi (Philadelphia Contributionship) ${ }^{9}$ ve Fransa'da kurulan Peynir Kooperatifi (Frutieres), kooperatif özellikleri içeren ilk

toplantının ana konularından biri olan sigorta hakkında pek çok makale ve kitap yazılmıştır. Ülkemizde ise "1. Uluslararası İslâm Ticâret Hukukunun Günümüzdeki Meseleleri Kongresi”nin (1996) ve “2. Uluslararası İslâm Ticâret Hukuku Kongresi”nin (2015) temel konularından birini teşkil etmiştir (Bayyiğit, Mehmet (Editör) (1997), 1. Uluslararası İslâm Ticaret Hukukunun Günümüzdeki Meseleleri Kongresi - 1996, "Sigorta Sonuç Bildirisi”, <http://www.islamticarethukuku.org/pageflip/magazine.php?no=6> s.e.t. 10.08.2020; Bayyiğit, Mehmet (Editör) (2016), 2. Uluslararası İslâm Ticaret Hukukunun Günümüzdeki Meseleleri Kongresi - 2015, "Sigorta Sonuç Bildirisi”, < http://www.islamticarethukuku.org/sigorta-oturumu-sonuc-bildirisi-70h.htm> s.e.t. 10.08.2020). Ayırca İslam Fikıh akademisi (1985 yılında ikinci dönem toplantısında) konuyu inceleyerek ticari sigortaların ribâ, garar, cehâlet ve kumar gerekçesi ile uygun olmadığı; yardımlaşmaya dayalı sigortanın İslam hukukuna uygun olduğu yönünde karar vermiştir. bk. Seyyid Muhammed Takiyyü'l-Hakîm, Abdu'l-Hâdî (2009) Akdü't-Te'mîn, Hakîkatuhû ve Meşrû'iyyetehû, Beyrut, Menşûrâtu'l-Halebiyyi'l-Hukukiyye, s. 288-290; Dalgın, Nihat (2009) “Sigorta”, Türkiye Diyanet Vakfı İslam Ansiklopedisi, İstanbul, TDV Yayınları, C: 37, s. 164.

9 University of California, "What is a Cooperative?" <http://sfp.ucdavis.edu/ cooperatives/what_is > s.e.t. 18.07.2020. 
örnekler olarak ifade edilmekle beraber günümüzde modern anlamdaki kooperatiflerin öncüsü olarak 24 Ekim 1844'te İngiltere'de kurulmuş olan Rochdale Tüketim Kooperatifi (The Rochdale Equitable Pioneers Society) görülmektedir. ${ }^{10}$

Kooperatif hareketinin ülkelerde doğuşu ve gelişimi incelendiğinde ilgili ülkelerin gelişmişliği ile doğru orantılı olduğu ve ülkelerin sosyalkültürel-ekonomik-siyasal durumlarıyla bağlantılı olarak her ülkede farklı özellikler gösterdiği gözlemlenmektedir. Küresel açıdan ele alındığında kooperatifler, 1900 yılına kadar orta düzeyde gelişmiş ülkelerde görülmekle beraber 1900'den 1917’ye kadar sanayi ülkelerinin sömürgesi olan ülkelerde ve daha ziyade tarımsal nitelikte olduğu görülmüştür. $\mathrm{Bu}$ dönemde 30 yeni ülkede kooperatif hareketi başlamış ve 1918'den 1945'e kadar kooperatifler, dönemin özelliği gereği sosyalist ülkelerde yeniden yapılanmıştır. 1945 sonrası dönem ise kooperatiflerin gelişme ve olgunluk dönemi olarak ifade edilmektedir. ${ }^{11}$

Ülkemizde Cumhuriyet dönemi ve öncesi kooperatifçiliğin tarihini incelediğimizde; Osmanlı döneminden önce kültürümüzde yardımlaşma, dayanışma ve fedakârlık gibi ilkeleri esas alan "imece", teşkilatlanmamış kooperatifçiliğin karakter özelliklerini göstermekle beraber kooperatiflere esin kaynağı olarak benzer ilk teşkilatlı yapının 13. yüzyılda esnaf ve sanatkâr meslek kuruluşları olarak ortaya çıkan "Ahi teşkilatı” olduğu ifade edilebilir. $\mathrm{Bu}$ teşkilatlar 17. yüzyılda loncalara dönüşmüş ve 19. yüzyılın ikinci yarısındaki gerileme döneminden sonra 1863 yılında "Memleket Sandığı" adı verilen ilk tarım kredi organizasyonu kurulmuştur. Bu kuruluş Türkiye'deki çağdaş kooperatifçiliğin doğuşunu temsil etmektedir. "Memleket Sandıkları"

10 Kizılaslan, Halil/Menek, Mehmet (2011), “Türkiye'de Kooperatiflerin Hukuki Statüsü ve Vergiler Karşısındaki Durumu”, ZKÜ Sosyal Bilimler Dergisi, C: 7, S: 13, s. 38; Üstün, Yusuf (2014a), "Sigorta, Tekafül ve Kooperatif Sigortacıllğı”, Karınca Dergisi, S: 927, s. 5; International Cooperative Alliance (ICA), "History of the cooperative movement", $<$ https://www.ica.coop/en/history-co-operative-movement> s.e.t. 20.08.2020; Ültanır, Memnune Sıla (2019), “Türkiye'de Kooperatifçiliğin Tarihsel Seyri: Devlet İnisiyatifiKalkınma İdeali” (Yüksek Lisans Tezi), Hacettepe Üniversitesi, Sosyal Bilimler Enstitüsü, s. 32.

11 Kizılaslan/Menek (2011), s. 38-39. 
zaman içinde kuruluş amacı kapsamındaki işlevini yerine getiremez olunca yerini 1883 yılında "Menâfi Sandıkları"na bırakmıştır. Daha sonra ise bu sandıklar 1888 yılında Ziraat Bankası'na devredilerek 1888-1913 dönemi bir duraklama dönemi olarak geçmiş ve 1913 yllında İstanbul'da ilk tüketim kooperatifi açılmıştır. Bundan sonra çok sayıda tüketim kooperatifi kurulmuş ancak hepsi 1919 yılında kapanmıştır. Kurtuluş Savaşı’nın kazanılmasının ardından 1920 yılında kooperatifleri yasal bir esasa dayandırmak amacıyla 77 maddelik Kooperatif Şirketler Kanun Layihası hazırlanmış, TBMM’ye sevkedilmiş, ancak bir kanuni düzenleme olarak hayat bulamamıştır. Çeşitli bölgelerde kooperatifler kurulmakla beraber Kooperatifçilik hareketinin tüm Türkiye’ye yayılması 2 Kasım 1935 tarihindeki “Tarım Satış Kooperatifleri Kanunu” ve "Tarım Kredi Kooperatifleri Kanunu” ile gerçekleşmiştir. 1954 tarihli 6762 sayılı TTK'da da "kooperatifler kitabı" ile daha nitelikli bir hale getirilen hukuki düzenlemeler, 1969 yılında 1163 sayılı "Kooperatifler Kanunu" ile bağımsız bir kanun haline gelmiştir. Ülkemizin ihtiyaçlarına göre değişen, iptal edilen ya da eklenen maddeleri ile günümüze kadar gelen bu kanun kendi bağımsız kanunu olan kooperatifler dışındaki tüm kooperatifler için uygulanmaktadır. ${ }^{12}$

Gerek ülkemizde gerekse diğer devletlerde kooperatif, sosyal amaçlı olarak ortaya çıkmış ve ülke yönetimleri tarafından desteklenmiştir. Türk hukuk sisteminde kendine has bir ortaklık modeli ile toplumun geniş bir kesimine hitap eden kooperatifler, ülkemizde üç ayrı bakanlığın ${ }^{13}$ görev ve sorumluluk alanında, 26 türde, 84.232 kooperatif ve 8.109 .225 ortak sayısı ile hizmet vermektedir. Üst örgütlenme olarak 571 Kooperatif Birliği ve 13 Kooperatif Merkez Birliği bulunmaktadır. ${ }^{14}$

12 T.C. Ticaret Bakanlı̆̆ı, “Tarihçe, Türkiye'de Kooperatifçilik”, $<$ https://ticaret.gov.tr/kooperatifcilik/kooperatifler-hakkinda-bilgiler/tarihce> s.e.t. 17.07.2020; Bilgin, Necdet/Şaban, Tanıyıcı (2008), “Türkiye'de Kooperatif ve Devlet İlişkilerinin Tarihi Gelişimi”, Karamanoğlu Mehmetbey Üniversitesi İİF Dergisi, C: 10, S: 15, s. 137-141; Ültanır, s. 32.

13 Bu üç bakanlık: Ticaret Bakanlığı; Tarım ve Orman Bakanlığı; Çevre ve Şehircilik Bakanlığı'dır.

14 T.C. Ticaret Bakanlığı, “Türkiye'de Kooperatifçilik”, <https://ticaret.gov.tr/kooperatifcilik /bilgi-bankasi/kooperatifler-hakkinda/turkiyede-kooperatifcilik> s.e.t.20.07.2020. 


\section{KOOPERATİFLERİN YAPISI VE İŞLEYIŞi̇}

İslam hukuku açısından tahliline zemin teşkil etmesi bakımından kooperatiflerin mahiyetini, kooperatife giriş ve ayrılış süreçlerini, temel ilkelerini, çeşitlerini, örgütlenme yapısını ve sorumluluk sınırlarını ortaya koymak önem arz etmektedir. Bütün bunları ortaya konulduktan sonra İslam hukuku açısından tahlil edilerek hukuki niteliği tespit edilmeye çalışılacaktır.

\section{A. TANIM}

Kooperatif, kelime olarak Latince “co" (birlik) ve “operatio” (çalışmak) kelimelerinin birleşiminden türetilmiş olup "birlikte çalışmak” anlamına gelir. Osmanlıca'da "teâvün sandığı” İngilizce'de “cooperative” Fransızca'da “coopérative”, Arapça'da "teâvunî (تعاوني)" kelimeleri ile ifade edilmektedir. ${ }^{15}$ Terim olarak kooperatif:16 "tüzel kişiliği haiz olmak üzere ortaklarının belirli ekonomik menfaatlerini ve özellikle meslek veya geçimlerine ait ihtiyaçlarını işgücü ve parasal katkılarıyla karşılıklı yardım, dayanışma ve kefalet suretiyle sağlayıp korumak amacıyla gerçek ve tüzel kişiler tarafından kurulan değişir ortaklı ve değişir sermayeli ortaklıklardır."(Koop.K. md. 1)

Yukarıdaki tanımdan da anlaşılacağı üzere klasik şirketlerde şirketin merkezinde sermaye ve amaç olarak "kâr" varken, kooperatifte; dayanışma niyeti ve gayreti gösteren insan vardır. Kooperatifçilikte birincil amaç kâr etmek değil karşılıklı yardım ve dayanışmadır ancak ikincil amaç olarak ekonomik çıktılar da söz konusudur. Dolayısı ile sosyal bir ihtiyacı da karşılayan ekonomik kuruluşlar olarak değerlendirmek mümkündür. ${ }^{17}$ Özü bakımından incelendiğinde ortaklarının ekonomilerini güçlendirmenin ve

15 Seyidoğlu, Halil (1992), Ekonomik Terimler Ansiklopedik Sözlük, Ankara, Güzem, s. 496; Hançerlioğlu, Orhan (1993), Ekonomi Sözlüğü. 5. Baskı. İstanbul, Remzi, s. 241; Hony, H. H. C./İz, Fahir (1992), The Oxford Turkish English Dictionary, Türkiye, İnkılâp/Oxford UniversityPress, 3. Bask1, s. 302.

16 Ayhan, Rıza/Çağlar, Hayrettin/Özdamar, Mehmet (2020), Şirketler Hukuku Genel Esaslar, Ankara: Seçkin yayınları, 2. Baskı, s. 171; Şener, s. 107.

17 Mollaoğlu, s. 46. 
korumanın yanında yardımlaşmayı, dayanışmayı ve kefaleti "karşılıklılık" kuralına uymak sureti ile gerçekleştiren ${ }^{18}$ sosyo-ekonomik bir oluşumdur.

Günümüzde önemli bir sosyal ve ekonomik hareket olarak kabul edilen kooperatifçilik toplumun sinerjisinin de ortaya çımasına hizmet eden önemli bir ortaklık çeşidi olarak belirli ilkelere göre çalışmaktadır.

\section{B. KOOPERATİFTE KURULUŞ, GİRIŞ VE AYRILIŞ SÜRECİ}

Kooperatif kuruluşunu daha sağlıklı değerlendirebilmek açısından girişten ayrılmaya kadarki süreci özetle aşağıdaki şekilde ifade edebiliriz: ${ }^{19}$

- Kooperatif en az 7 kişi (gerçek ya da tüzel) tarafından imzalanacak anasözleşme ile kurulur. Anasözleşmedeki imzaların Ticaret Sicili Müdürlügü̈nce onaylanması gerekir.

- Kooperatif ticaret siciline tescil ile tüzel kişilik kazanır.

- Kurulduktan sonra kooperatife girmek isteyenler; fiil ehliyetine sahip gerçek kişiler ile 1163 sayılı Kooperatifler Kanunu'nda sayılan tüzel kişiler, yönetim kuruluna "kooperatif anasözleşmesini bütün hak ve mükellefiyetleri ile kabul ettiklerini belirtir şekilde" yazılı olarak başvurur.

- Başvuran kişi için bir ortaklık payının değeri 100 (Yüz) TL'dir. Ortaklar en çok 5.000 pay taahhüt edebilirler.

- Başvuru değerlendirilir ve yönetim kurulunca alınacak kararı müteakip ortaklık sıfatını haiz olur.

- Ortaklar kooperatifçilik ilkeleri çerçevesindeki hakları ve sorumlulukları kapsamında;

a. İşücü ve parasal katkı sunar,

b. Birbirlerinin yardımcısı ve kefili olur,

c. Belirli bir ekonomik menfaat elde eder,

\section{Üstün (2014a), s. 8.}

19 Üstün, Yusuf/Aydın, Muhittin (2014), Kooperatifler Hukuku, Ankara, Banka ve Ticaret Hukuku Araştırma Enstitüsü, s. 51-86; T.C. Ticaret Bakanlığı, "Kooperatif Nasıl Kurulur?”, $<$ https://ticaret.gov.tr/kooperatifcilik/kooperatif-nasil-kurulur> s.e.t. 20.07.2020. 
d. Meslek ve geçimine ait ihtiyaçlarını karşılama imkânına kavuşur.

e. Kooperatiflerin sorumluluğu; anasözleşmesinde aksine bir düzenleme bulunmadığı sürece alacaklılarına karşı sadece malvarlı̆ğ ile olacak şekilde "sınırlı sorumluluk"tur.

- Ayrılmak isteyen ortak istediği zaman kooperatiften ayrılabilir.

\section{KOOPERATİFÇİLIKK İLKELERİ}

Günümüzde kooperatifçilik, Uluslararası Kooperatifler Birliği tarafından kabul edilen aşağıdaki ilkelere ${ }^{20}$ göre yürütülmektedir:

1. Açık kapı ilkesi: Kooperatife serbest girişi ifade eder. Yani kooperatifin hizmetlerinden yararlanabilecek ve üyeliğin sorumluluklarını kabule rıza gösteren gerçek ya da tüzel kişilere hiçbir ayrımcilık (cinsel, sosyal, ırksal, siyasal, vd.) yapılmaksızın giriş hakkı verilir. "Açık kapı ilkesi” gerçek ve tüzel kişilerin anasözleşmede yer alan ortaklık şartlarını taşımaları ile sınırlıdır.

2. Demokratik yönetim ve eşitlik ilkesi: Kooperatifteki sermaye oranlarına bakılmaksızın her ortağın sadece bir oya sahip olmasını ve ortaklığ 1 oluşturan kişilerin bir araya gelerek yönetim görevini yürütmesini ifade eder. ${ }^{21} \mathrm{Bu}$ ilke, kooperatiflerde asıl gücün insan unsurunda odaklandığını işaret etmesi bakımından sermaye şirketlerinden farklı bir yönü ortaya koyar.

3. İşletme fazlalarının işle orantılı olarak dağıtılması (risturn) ilkesi: Kooperatiflere nasıl yatırım yapılacağı ve sağlanan işletme fazlasının nasıl paylaşılacağı kooperatif ortakları tarafından belirlenir. Ortaklar, genel kurulca alınan kararlar gereği belirli bir aidat ve ek

20 Kooperatifçilik ilkeleri, Uluslararası Kooperatifler Birliği'nin (ICA-International Cooperative Alliance) 7 Eylül 1966 tarihinde Viyana'da gerçekleştirilen 23. Kongresinde kabul edilmiş ve 20-23 Eylül 1995 tarihleri arasında İngiltere'nin Manchester şehrinde yapılan 31. Kongresinde tartışlarak yeniden şekillenmiştir. (T.C. Ticaret Bakanlı̆̆ı, "kooperatifçilik İlkeleri”, <https://ticaret.gov.tr/kooperatifcilik/kooperatifler-hakkinda-bilgiler/kooperatifcilik-ilkeleri> s.e.c. 17.07.2020).

21 Mollaoğlu, s. 12. 
ödemelerle yükümlüdürler. Bununla birlikte kooperatifin elde ettiği olumlu gelir-gider farkından kooperatifle yaptıkları muameleleri oranında ödeme (risturn) isteme hakkına sahiptirler. Kooperatifin tasfiyesi halinde de arta kalan tasfiye artığından faydalanırlar. Sermaye şirketlerinde kâr dağıtımı sermaye payına göre yapılırken kooperatiflerde kâr, sermaye şirketlerinden farklı olarak ortağın sahip olduğu sermaye payına değil kooperatifle yaptıkları işe veya gördükleri hizmete göre paylaştırılır. Bu ilke (risturn), kooperatifine sahip çıkan ve kooperatifine daha çok iş yapan ortaklara yıl sonunda verilen bir ödül olarak değerlendirilmesinin yanında eşitlik ve adalet prensibinin bir sonucu olarak da kabul edilir.

4. Özerklik ve bağımsızlık ilkesi: Kooperatifçiliğin uygulandığı bütün ülkelerde hükümetlerin belirlediği kanuni çerçevede özerk, kendi kendine yeten ve ortaklarınca yönetilen kuruluşlar olduğunu ifade eder. Ülkemizde 1163 sayılı Kooperatifler Kanunu ile özerk bir yapıya sahiptir. Bazı durumlarda TTK ve Vergi Usul Kanunu (VUK) hükümleri uygulansa da kuruluş aşamasından dağılmasına kadara tüm işlemler Kooperatifler Kanunu'na göre yürütülür ve bu da ona özerklik kazandırmaktadır.

5. Eğitim, öğretim ve bilgilendirme ilkesi: İlke, kooperatifin gelişimine etkin bir katkı sunabilmesi amacıyla seçilmiş temsilcilerine, yöneticilerine, ortaklarına eğitim ve öğretim imkânı sağlanması ve aynı zamanda kooperatifçilik konusunda halkın bilgilendirilmesini ifade eder. Bu görev ülkemizde daha ziyade kooperatif üst kuruluşlarına verilmiştir (Koop.K, md. 70, 75). Kooperatifçilikteki eğitim-öğretim ile amaçlanan, ilgili tarafların kooperatifçiliği kavrama ve özümsemelerini sağlayarak sorumluluklarını etkili olarak yerine getirebilmeleri için gerekli yeteneklere kavuşturmaktır.

6. Kooperatifler arasında iş birliği ilkesi: İlke, kooperatifin diğer kooperatiflerle yerel, bölgesel, ulusal ve uluslararası düzeyde iş birliği yapmasını ifade eder. Bu ilkeyi işleten kooperatifler, ortaklarına optimum seviyede hizmet sunma ve kooperatifçilik hareketini 
güçlendirme imkânına kavuşur. $\mathrm{Bu}$ ilke aynı zamanda kooperatiflerin açılık ve evrensellik özelliklerinin de gereğidir.

7. Topluma karşı sorumlu olma ilkesi: İlkeye göre, kooperatifin geliştirdiği politikalar vasıtasıyla içinde yaşadığı toplumun sürdürülebilir kalkınması için çalışması gerekir. Yani kooperatif, ortaklarının çıkarlarını sağlamanın yanında içinde yaşadığı topluma karşı da belirli bir sosyal sorumluluğu yerine getirmekle mükelleftir. Bu ilke 1995 yılında belirlenmiş olup diğer altı ilkeye nazaran yeni bir ilkedir. ${ }^{22}$

\section{KOOPERATIFF TÜRLERI}

Ülkemizde kooperatifler ile ilgili genel kanun 1163 sayılı Kanun olmakla birlikte, belirli kooperatifler için özel düzenlemeler de yapılmıştır. 1163 sayılı Kanun, aynı zamanda, özel kanunlarda düzenlenmeyen konularda kooperatifler için yedek hukuk kuralları içerir (Koo.K, md. 96).

Kooperatifler çalışma konularına göre çeşitlenmektedir. ${ }^{23}$ Kooperatifler Kanununda bu konuda yapılmış bir tasnif veya faaliyet konusu bakımından bir sınırlamaya yer verilmemiştir. Hakkında hukuki düzenleme yapılan kooperatifler açısından “özel kanunu olan kooperatifler” ve "1163 sayılı Kooperatifler Kanunu'na tabi olan kooperatifler” şeklinde ikiye ayırmak mümkündür, ${ }^{24}$ ancak literatürde en yaygın ayrım, konularına göre yapılan ayrım olup bu çerçevede; üretim, tüketim, yapı, kredi ve sigorta kooperatifleri şeklinde ayırmak mümkündür. Bu ayrımı bilimsel yöntemler izleyerek sınıflandırmak ve türlere ayırmak oldukça zordur, zira hem ülkemizde hem de diğer ülkelerde çalışma alanlarına göre kurulmuş yüzlerce kooperatif vardır. ${ }^{25}$

22 Mollaoğlu, s. 12-17; $\quad$ T.C. Ticaret Bakanlığı, "kooperatifçilik İlkeleri”, $<$ https://ticaret.gov.tr/kooperatifcilik/kooperatifler-hakkinda-bilgiler/kooperatifcilik-

ilkeleri> s.e.c. 17.07.2020; International Cooperative Alliance (ICA), "Cooperative identity, values \& principles", <https://www.ica.coop/en/cooperatives/cooperative-identity> s.e.t. 20.08 .2020

23 Mollaoğlu, s. 53.

24 Mollaoğlu, s. 63.

25 Mollaoğlu, s. 53. 
Ülkemizdeki pratik uygulamayı esas alarak bağlı bulundukları bakanlıklara göre üç grupta ele alabileceğimiz kooperatifleri şu şekilde siralayabiliriz: ${ }^{26}$

a) Tarım ve Orman Bakanlığına bağlı kooperatif çeşitleri: Tarımsal kalkınma kooperatifleri, sulama kooperatifleri, su ürünleri kooperatifleri, pancar ekicileri kooperatifleri, tarım kredi kooperatifleri.

b) Ticaret Bakanlığına bağlı kooperatif çeşitleri: Tarım satış kooperatif ve birlikleri, esnaf ve sanatkârlar kredi ve kefalet kooperatifleri, tüketim kooperatifleri, motorlu taşıyıcılar kooperatifleri, turizm geliştirme kooperatifleri, kadın kooperatifleri, temin ve tevzi kooperatifleri, üretim ve pazarlama kooperatifleri, küçük sanat kooperatifleri, sigorta kooperatifleri.

c) Çevre ve Şehircilik Bakanlığına bağlı kooperatif çeşitleri: Konut yapı kooperatifleri, küçük sanayi siteleri işyeri yapı kooperatifleri, toplu işyeri kooperatifleri.

\section{E. KOOPERATIFLERIN ÜST ÖRGÜTLENMESİ VE DENETIMİ}

Kooperatiflerde üst örgütlenme, birim örgüt olan kooperatiften başlayarak yukarıya doğru ulusal birliğe kadar ülke düzeyinde tedrici olarak örgütlenmeyi ifade eder. Avrupa ve Amerika'da 19. yüzyılda başlamış olan üst örgütlenmeler ülkemizde 1969 yılında 1163 sayılı Kanun ile başlamıştır.

Ülkemizde birim kooperatifler bir araya gelerek "Bölge Birliği”, bölge birliklerinin "Merkez Birliği", bütün birlik ve merkez birliklerin ise "Milli Birliği” oluşturması öngörülmüştür. Türkiye Milli Kooperatifler Birliği 1991 yılında kurulmuştur. ${ }^{27}$ Bazı hukukçular tarafından aşağıdan yukarı doğru piramit şeklinde dikey bir örgütlenme ${ }^{28}$ olduğu ifade edilmekle beraber

26 Üstün/Aydın, s. 29-42.

27 Üstün/Aydın, s. 331; Türkiye Kooperatifler Birliği, "Türkiye Milli Kooperatifler Birliği

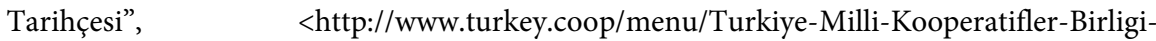
Tarihcesi/11> s.e.t. 18.07.2020.

28 Mülayim, Ziya Gökalp (2012), “Kooperatif Kuruluşlarda Üst Örgütlenmenin Önemi ve Türkiye'de Sorunları", İstanbul Üniversitesi, Sosyal Siyaset Konferansları Dergisi, S: 40, s. 33. 
kurulan birliklerin de unvanlarında sadece "birlik" kelimesi geçen birer "kooperatif” olarak kurulduğu göz önüne alındığında yatay bir örgütlenme olarak düşünmek de mümkündür. Kooperatif birlikleri ve Merkez birlikleri gibi Milli birlik de kooperatif şeklinde kurulur (Koop.K.md. 72).

Kooperatiflerin iş ve işlemleri, 1163 sayılı Kanun kapsamında iç denetim, dış denetim ve üst denetim şeklinde denetlenmektedir (Koop.K md. 90). Ticaret Bakanlı̆̆ı, Türkiye Milli Kooperatifler Birliği'nden başlayarak aşağıya doğru tüm kooperatifleri denetlemek ya da denetlettirmek ile görevli ve yetkilidir. ${ }^{29}$

\section{F. KOOPERATIFLERDE SORUMLULUK SINIRLARI}

Ticaret şirketlerinde, ortak veya pay sahiplerinin şirket borçlarından dolayı sorumluluğu ve bunun sınırı önemli konuların başında gelmektedir. $\mathrm{Bu}$ sorumluluk şahıs şirketlerinin aksine sermaye şirketlerinde sınırlıdır. Ortak veya pay sahibinin şirkete getirmeyi taahhüt ettiği sermaye payı, onun sorumluluğunun da sınırını oluşturmaktadır. Bu sorumluluk kural olarak şirketin alacaklılarına karşı değil, şirkete karşıdır.

Kooperatiflerde ortakların sorumluluğu, ortakların kooperatif tüzel kişiliğine ait borçlardan sorumluluğunu ifade eder. Bu, sui generis bir sorumluluk olup, "sınırsız sorumluluk" veya "sınırlı sorumluluk" şeklinde (Koop.K md. 29, 30) ortaya çıkabilir. ${ }^{30}$ Kooperatifler, anasözleşmesinde aksine bir düzenleme bulunmadığı sürece, alacaklılarına karşı sadece kendi malvarlığı ile ve sınırlı sorumludur. Ancak kooperatif anasözleşmesinde açıkça belirtilmek şartıyla sorumluluğun ortakları da kapsayacak şekilde genişlemesi, bu kapsamda ortakların "sınırsız sorumlu" veya "belirli bir miktarla sınırlı sorumlu” olması mümkündür. Ortakların sınırsız sorumluluk

29 T.C. Ticaret Bakanlığı, “Denetim İşlemleri”, <https://www.ticaret.gov.tr /kooperatifcilik/kooperatiflere-yonelik-hizmetler/denetim-islemleri> s.e.t. 20.07.2020.

30 Gürbüz, Diğdem Göç (2010), "Kooperatiflerde Ortakların Sorumluluğu”, Marmara Üniversitesi İİBF Dergisi, C: 28, S: 1, s. 465-466; Üstün, Yusuf (2014b), "Normlar Hiyerarşisi Ve Kooperatiflerin Denetimi Meselesi”, Tematic Ticaret ve Mevzuat Araştırmaları Dergisi, S: 2, s. 1-10, <https://ticaret.gov.tr/data/5d41e48b13b876 39ac9e02df/1794d24757d0ddfc277bd3ca1fa54a5d.pdf> s.e.t. 20.08.2020. 
alacak kadar şahsi sorumluluk üstlenmelerindeki ana gaye, kooperatifin daha geniş bir çalışma alanına kavuşması ve daha güvenli, itibarlı hale gelmesidir. Çalışma ortamındaki gelişmelere göre kooperatif ortaklarının sorumluluklarının değiştirilmesi (Koop.K.md. 51,52) mümkündür. ${ }^{31}$ Kooperatiflerde sorumluluğun sadece belirli ortaklara yüklenmesi ya da belirli bir zamana bırakılması mümkün değildir (Koop.K.md. 32). ${ }^{32}$

\section{III. İSLAM HUKUKUNDA KOOPERATIF İLE İLGILI TARTIŞMALAR}

İslam hukukunda kooperatif ile ilgili tartışmalar daha ziyade sigorta konusu ile başlayıp kooperatifin bir çeşidi olan sigorta kooperatifi kapsamında gerçekleşmiştir. Sigortanın İslam hukuku açısından uygunluğunun tartışılması Osmanlı döneminde Batı'da gerçekleşen sigorta faaliyetlerinin Müslümanlar tarafından uygulanabilirliğinin sorgulanması ile başlamıştır. Kooperatif konusuna da kaynaklık etmesi yönüyle aşağıda bu tartışmaların bir kısmına yer verilmiştir.

$\mathrm{Bu}$ konuda ulaşabildiğimiz ilk değerlendirme, dönemin önde gelen İslam hukukçusu İbn Âbidîn'e aittir. Sigortaya dair değerlendirmesinde, Müslümanlar arasında caiz olmadığını ancak harbî ile Müslümanın harbî ortağı arasında yapılabileceğini ifade etmiştir. ${ }^{33}$

Bu konuda 1870'de İstanbul'da Beyoğlu Feridiye yangını sonrası Meşihat makamının (fetvanın tam metnine ulaşılmamakla beraber) câiz olduğu yönünde fetvası, 1901 yılında Mısır Baş Müftüsü Muhammed Abduh'un hayat sigortasının caiz olduğu yönünde fetvası mevcuttur. Osmanlı

\footnotetext{
Mollaoğlu, s. 72-86.

Üstün-Aydın, s. 146.

İbn Âbidin, Muhammed Emîn b. Ömer b. Abdilazîz (1995), Reddu'l-Muhtâr, Beyrut, Dâru'l-Fikr, C: 4, s. 350; İbn Âbidin, Muhammed Emîn b. Ömer b. Abdilazîz (1325), Mecmûatu'r-Resâil, İstanbul, Şirket-i Sahafiye-i Osmaniye, C: 2, s. 177-178; Hacak, Hasan (2006), "İslâm Hukukunda Sigorta ve Fıkıh Bilginlerinin Sigortaya Yaklaşımının Genel Bir Değerlendirmesi”, M.Ü. İlâhiyat Fakültesi Dergisi. C: 30, S: 1, s. 21-50; Seyyid Muhammed Takiyyü'l-Hakîm, s. 292.
} 
devletinde 1911 yılında Meşihat kapısına yönlendirilen bir kimseye İbn Âbidîn'in görüşüne benzer bir fetva verildiği bilgisi vardır. ${ }^{34}$

1960 ’lı yıllara kadar sigortanın cevazına dair olumlu ve olumsuz görüşler beyan edilmiştir, ancak derinlemesine tahlillere rastlanmamaktadır.

Ticari sigorta ve yardımlaşmaya dayalı sigorta, 1960’lı yıllardan sonra İslâm dünyasının değişik yerlerinde düzenlenen ilmî toplantı, kongre ve sempozyumların konusu olmuştur. Bu konu ile ilgili geniş katılımlı, uzun soluklu inceleme ve komisyon çalışmaları yapılmıştır. Bu kapsamda Ezher Üniversitesi (Mısır) bünyesinde gerçekleştirilen 2. İslâm Araştırmaları Toplantısı'nda (1965) “yardımlaşmaya dayalı sigorta"nın meşru olduğu, ticari olanlarla ilgili bilimsel araştırma yapılması gerektiği görüşü benimsenmiştir. İslam Fıkıh Akademisi'nin (Dünya İslâm Birliği'ne bağli) 1977'de Riyad'daki toplantısında üyeler "karşılıklı sigortaların câiz olduğu" görüşünde ittifak etmiş; 1978'de Mekke'deki toplantısında ise üyelerin cumhuru ticari sigortanın bütün çeşitleriyle haram olduğuna karar vermiştir. İslâm Fıkıh Akademisi (İslâm Konferansı Teşkilâtı'na bağlı) 1985'te ikinci dönem toplantısında; ticari sigorta şirketlerinin dinen haram, ancak teberru ve karşılıklı yardım esasına dayanan "yardımlaşma sigortası”nın meşru olduğu görüşünü benimsemiştir. Ticari sigorta şirketlerinin sözleşmelerinin haramlığının gerekçesi olarak; garar (akdi geçersiz kılacak ölçüde büyük belirsizlik), cehâlet, ribâ/faiz ve kumar özelliği gösterilmiştir. Zira sigortalılar uzunca süre prim ödediği halde risk meydana gelmediği hallerde hiçbir sigorta tazminatı alamadığı durumlar olabilmesine karşılık, sigorta riskinin oluşması durumunda az prim ödemiş olsa ya da sözleşmeyi henüz imzalamış olduğu için hiç prim ödememiş olsa bile yüksek miktarda tazminat alabilmektedir. Ayrıca ticari sigortada ödenen prim ve prime karşılık verilen sigorta tazminatı nakit ve aynı cinsten olduğu için ödediği prime eşit alması halinde nesîe ribâsı (gecikme faizi), fazla olması halinde de hem fazlalık ribâsı (faizi) hem de nesîe ribası gerçekleşmiş olmaktadır şeklinde yorumlanmıştır. ${ }^{35} \mathrm{Bu}$ yorumlar daha

34 Hacak (2006), s. 35.

35 Karaman, Hayrettin (1992), İslam'a Göre Banka ve Sigorta, İstanbul, Nesil, s. 13-24; Zerkâ, M. Ahmed, (1992) "İslâm'a Göre Sigorta”, (Çeviren: Karaman, Hayrettin), İslam’a Göre Banka ve Sigorta, İstanbul, Nesil Yayınları, s. 203-245; Hacak (2006), s. 36; Hacak, Hasan 
ziyade günümüz İslam dünyasındaki dört büyük mezhebin (Hanefi, Maliki, Şafii ve Hanbeli) akit teorisi bağlamındaki görüşleri doğrultusunda ileri sürülmüştür. $\mathrm{Bu}$ mezheplerin usul ve füruunda farklılıklar olmakla beraber ilgili toplantılara katılan İslam hukukçuları ilgili mezheplerin ilkelerinden hareketle belirli bir görüşte ittifak sağlayamamışlar ve karar cumhurun kararı olarak verilmiştir. 1. Uluslararası İslâm Ticaret Hukukunun Günümüzdeki Meseleleri Kongresi'nde (Konya-1996) "prensip olarak sigorta sisteminin câiz ve gerekli” olduğu ancak günümüzdeki sigorta uygulamalarının düzeltilmesi gereken bazı unsurlar içerdiği kabul edilmiştir. ${ }^{36} 2$. Uluslararası İslâm Ticaret Hukukunun Günümüzdeki Meseleleri Kongresi’nde (Konya-2015) ise ticari sigorta, fikhın sabit ilkeleri ile çatışma olmayacak şekilde düzenlenmek şartıyla caiz görülmüş; yardımlaşmaya dayalı "tekâfül” sigorta sisteminde meşru birtakım yeni finansal araçlar geliştirilmesi tavsiye edilmiştir. ${ }^{37}$ Tartışmaların neticesinde sigorta ile ilgili öne çıan görüşleri üç temel grupta toplamak mümkündür: ${ }^{38}$

a) Sigorta kurumunun tümüne karşı çıan görüş,

b) "Karşılıklı yardımlaşma amaçlı sigorta caizdir, ancak ticari sigorta caiz değildir” yönündeki görüş,

c) "Ticari sigorta ve karşılıklı yardımlaşma amaçlı sigorta caizdir” görüşü.

(2016), "İslam Hukukunun İlkeleri Açısından Alacak (Kredi) Sigortası”: Mehmet Bayyiğit (Editör), 2. Uluslararası İslâm Ticaret Hukukunun Günümüzdeki Meseleleri Kongresi, Konya, KTO Karatay Üniversitesi, s. 1011-1023; Dalgın (2009), s. 159-164; Dalgın, Nihat (1997) “Kaza, Hayat ve İşsizlik Sigortalarına Yeni Bir Yaklaşım”: Mehmet Bayyiğit (Editör), 1. Uluslararası İslâm Ticaret Hukukunun Günümüzdeki Meseleleri Kongresi, Konya, Kombad, s. 878-889.

36 1. Uluslararası İslâm Ticaret Hukukunun Günümüzdeki Meseleleri Kongresi (1996), "Sigorta Sonuç Bildirisi", <http://www.islamticarethukuku.org/pageflip/magazine.php? no=6> s.e.t. 10.08.2020; Dalgın (2009), s. 159-164; Hacak (2016), s. 1042.

37 2. Uluslararası İslâm Ticaret Hukukunun Günümüzdeki Meseleleri Kongresi (2015), "Sigorta Sonuç Bildirisi", <http://www.islamticarethukuku.org/sigorta-oturumu-sonucbildirisi-70h.htm> s.e.t. 10.08.2020.

38 Seyyid Muhammed Takiyyü'l-Hakîm, s. 305-310; Beşer, Faruk (1988), İslam'da Sosyal Güvenlik, İstanbul, Sehâ Neşriyat, 1988, s. 226; Hacak (2006), s. 37. 
$\mathrm{Bu}$ tartışmaların neticesinde İslam âleminde "tekâfül”, "İslamî sigorta"; ${ }^{39}$ ülkemizde ise "katılım sigortacılı̆̆ı" adıyla yürütülen karşılıklı yardımlaşmaya dayalı sigorta çeşidi uygulama alanı bulmuş ve gelişimini sürdürmektedir. Yardımlaşmaya dayalı sigorta çeşidi kooperatif ortaklığının sadece bir çeşidini oluşturmakla beraber temel felsefesine 1 şı tutması bakımından önem arz etmektedir. Zira her ikisinde de katılımcılar için risk paylaşımı söz konusudur, ancak iş ve işlemlerinde farklılıklar vardır.

\section{KOOPERATIFLERIN HUKUKİ NITELİĞİ VE İSLAM HUKUKU AÇISINDAN TAHLİLI}

Kooperatifler ilk bakışta karşılıklı yardımlaşma, dayanışma ve kefalet esasına dayalı bir ortaklık yapısı arz etmekte ve bu özelliği ile kâr elde etme ve bunu paylaşma odaklı diğer ticaret şirketlerinden ayrılmaktadır.

Kooperatifin hukuki niteliği pozitif hukuk kapsamında hukukçular arasına tartışma konusu olmuş ve Türk Ticaret Kanunu'nda şahıs ve sermaye şirketleri arasına sayılmayarak ticaret şirketi olarak ifade edilmiştir (TTK, md. 124). İslam hukukunda kooperatif ile aynı özden hareket eden sözleşme tipleri olmakla beraber klasik şirketler arasında birebir örtüşen bir ortaklık sözleşmesine rastlanmamıştır.

Aşağıda İslam şirketler hukukundaki yerini genel olarak tespit ettikten sonra kooperatifin unsurlarını ve Türk hukukundaki hukuki nitelendirmeyi göz önüne alarak İslam hukuku açısından hukuki niteliğini tespit etmeye çalışacağız.

\section{A. KOOPERATİFIN HUKUKİ UNSURLARI AÇISINDAN TAHLİLI}

İslam hukukunda iki veya daha çok kişinin sermaye, emek ya da itibarlarının birleşiminden meydana gelen ortaklık "şirket” olarak adlandırılır. Bir mal, hak veya menfaate müştereken sahip olmak da "şirket" kavramı ile

39 AAOIFI, The Accounting and Auditing Organization for Islamic Financial Institutions Shari'ah Standards (2015), Bahryen, Dar AlMaiman (Çeviren: Sabahattin Zaim Üniversitesi (2018), Faizsiz Finans Kuruluşları Muhasebe ve Denetleme Kurumu Faizsiz Finans Standartları 2015, İstanbul, TKBB), s. 662-685. 
ifade edilir. ${ }^{40}$ "Şirket", bir sözleşme sonucu iradi olarak gerçekleşebileceği gibi bir mirasa iki ya da daha çok kişinin mirasçı olmaları sonucu gerçekleşen ortaklıkta olduğu gibi gayri iradi olarak da gerçekleşebilir. ${ }^{41}$

Kooperatiflerde ortakların bir anasözleşme etrafında bir araya gelmesi söz konusu olduğu için klasik üçlü ayrıma göre ${ }^{42}$ "akit şirketleri” kapsamındaki şirket çeşitleri içinde değerlendirilebilir. Zira akit şirketleri iki ya da daha fazla kişinin sermaye ve kâr üzerine kurdukları ortaklıktır. ${ }^{43} \mathrm{Bu}$ şirket türünün esasını, şartlarını ortakların belirlediği sözleşme oluşturur. Kooperatifte de benzer şekilde ortaklar bir "anasözleşme" çerçevesinde bir araya gelmektedirler.

Günümüz hukuk mevzuatında da şirket kapsamında sayılan kooperatifler bazı yargı kararlarında ${ }^{44}$ ve bazı hukukçular tarafından "derneklerden ve ortaklıklardan farklı kişi birlikleri” olarak ifade edilmiştir. ${ }^{45} \mathrm{Bu}$ görüşün gerekçesi olarak da tüzel kişilik olan kooperatiflerin kısmen derneklere ve ortaklıklara benzer yönleri olmakla beraber kendine has (sui generis) bir yapısının olması gösterilmiştir.

Kooperatifler, Türk Ticaret Kanunu'nda (TTK) ne sermaye ne de kişi ortaklıkları arasında sayılmıştır (TTK, 124/2). Şener, bu tür ortaklıkların nitelikleri ile doğrudan bağlantılı olduğunu vurgulayarak, bu durumun bilinçli olarak tercih edildiğini ifade eder. ${ }^{46}$ Kooperatiflerde hem kişi hem de sermaye

40 İbn Manzûr, Ebu'l-Fazl Cemaluddin Muhammed b. Mukerrem (1990), Lisanu'l-Arab, Beyrut, Daru Sadır, C: 10, s. 448; Erdoğan, Mehmet (1998), Fıkıh ve Hukuk Terimleri Sözlüğü, İstanbul, Rağbet, s. 422.

${ }^{41}$ Serahsî, Ebû Bekr Şemsü'l-Eimme Muhammed b. Ebî Sehl Ahmed (1989), el-Mebsût, Beyrut, Dâru'l-Fikr, C: 11, s. 151; Ahmet Cevdet Paşa (1985), Açıllamalı Mecelle, (Metin ve Açılamaları Kontrol Eden: Ali Himmet Berki), İstanbul, Hikmet, Mecelle, md. 1045.

42 Klasik üçlü ayrım; ibâha şirketi, mülk şirketi ve akit şirketi.

43 Kudûrî, Ahmed b. Muhammed (2018), el-Kitâb Muhtasaru'l-Kudûrî Fi'l-Fıkhi'l-Hanefî, Konya, Burç. s. 104; Ebu Ceyb, Sadi (1988), el-Kâmûsu'l-Fıkhiyye, Dımeşk, Dâru'l-Fikr, s. 256.

44 Mollaoğlu, s. 92.

45 Poroy, Reha/Tekinalp, Ünal/Çamoğlu, Ersin (2017) Ortaklıklar Hukuku II, 13. Baskı, İstanbul, Vedat Kitapçılık, s. 588.

46 Şener, s. 108. 
ortaklıklarına has özelliklerle karşılaşıldığı gibi her ikisinde de görülmeyen sadece kooperatiflere has özelliklere rastlamak da mümkündür. Mesela, kooperatiflerde sermaye ortaklarına has olarak ortağın ölümü ortaklığın sona erme sebepleri arasında sayılmadığı gibi (Koop.K, md. 14/1, 81), ortaklar esas itibariyle alacaklılara karşı sorumlu da değillerdir (Koop.K, md. 28). Kişi ortaklarına has özellikler olarak her ortağın bir oy hakkına sahip olması (Koop.K, md. 48), hak ve yükümlülüklerde eşitlik (Koop.K, md. 23) öne çıkmaktadır. Ayrıca kooperatiflerde kâr paylaştırmanın da esas olmaması (Koop.K, md. 39) diğer ortaklıklardan ayrı olarak sadece kooperatiflere has bir özelliktir. Dolayısı ile kooperatifler hem kişi hem de sermaye şirketi özelliklerini taşıması sebebiyle ayrı bir yerde durmaktadır. Bu durumun bir sonucu olarak TTK, kooperatifleri kişi ve sermaye ortaklıkları arasında saymamış ve ticaret ortaklığı olarak kabul etmiştir. ${ }^{47}$

İslam hukukunda günümüz pozitif hukuk sistemlerinde olduğu gibi ticaret şirketi altında yapılan şahıs ve sermaye şirketi ayrımı yerine farklı bir tasnif söz konusudur. Şirketler yetki dengesi bakımından "mufâvada şirketi” ve "inan şirketi"; konusu bakımından ise "şirket-i emvâl", "şirket-i a'mâl" ve "şirket-i vücûh" şeklinde sınıflandırılmıştır. ${ }^{48}$ İslam akit teorisi ile uyumlu olmak kaydıyla akit serbestisi kapsamında yeni şirketler oluşturmak da mümkün görülmektedir. ${ }^{49}$

İslam hukukunda gerek yetki dengesi, gerekse konusu bakımından kooperatiflerle birebir örtüşen bir şirket yapısı görülmemektedir. "İki ve daha çok kişinin eşitlik şartı aranmaksızın” bir araya gelmesi açısından "akit şirketleri” kapsamındaki "inan şirketi” ile daha uyumlu kabul edilebilecek olan kooperatifleri; amaç, serbest katılma ve çıkma, ortak, tüzel kişilik, unvan,

\footnotetext{
Şener, s.108-109.
}

48 Zuhaylî, Vehbe (1989), el-Fıkhu’l-İslâmî ve Edilletuhû, Dımeşk, Dâru'l-Fikr, C: 4, s. 796803; Yaman, Ahmet/Çalış, Halit (2018), İslam Hukuku, Ankara, Bilay, s. 335.

49 Akit serbestisinin kapsamı için bk. Haçkalı, Abdurrahman (2002), "İslam Hukuku Açısından Akit Serbestisi Prensibi”, Dini Araştırmalar, C: 5, s. 13, 119-136; Çalış, Halit (2004), "İslâm Borçlar Hukukunda Akit Serbestisi ve Genel Olarak Sınırlamaları", Dini Araştırmalar, C: 7, S: 19 s. 269-295. 
sermaye (malvarlığı), eşitlik ve demokratik yönetim unsurları açısından aşağıdaki şekilde tahlil edebiliriz.

\section{Amaç Unsuru}

Amaç unsuru açısından kooperatifler diğer tüzel kişilerden farklıdır. Şirketlerde "kâr" amacı öne çıkarken kooperatiflerde öncelikli olarak "karşılıklı yardımlaşma, kefalet ve beraberinde ortakların menfaati" öne çıkmaktadır. Tüzel kişiliğe sahip olan vakıf, sendika ve dernekler ile "yardımlaşma-dayanışma" amacı bakımından benzerlik göstermektedir. Şirketlerde olduğu gibi amaç, salt kâr elde etmek olmamakla beraber kooperatiflerde şirketlerdeki "kâr"a karşılık gelen menfaatin iki şekilde ortaya çıktığg görülmektedir.

Birincisi, ortak içi işlemlerden elde edilen hasıla (risturn) "olumlu gelirgider farkının belli kurallara göre ortaklara dağıtılması” mümkündür. Kooperatiflerin nihai hedefi ortaklara hizmet olup ancak anasözleşmede belirtildiği takdirde "olumlu gelir-gider farkı" paylaştırılabilir. Anasözleşmede belirtilmemişse bu fark, kooperatifin gelişimini sağlamak üzere özel bir fonda toplanir. $^{50}$

İkincisi ise, kooperatif ortak dışı işlem yaparsa ${ }^{51}$ bu durumda sermaye şirketinden farkı yoktur ve bu hesaplardan elde ettiği kâr, ortaklara sermaye payları oranında aynı temettü de olduğu gibi dağıtılabilir. Bu dağıtımın yapılıp yapılmaması ya da kooperatifte kalması anasözleşme veya genel kurul kararı ile belirlenir.

Kooperatif, kuruluş amacını gerçekleştirme için iş gücü ve parasal katkı kullanmaktadır. Bu durum kooperatifin hem kişi hem de sermaye öngörüsünün olduğunun bir delildir. Karşılıklı yardım ve dayanışma ise kooperatifin felsefi ve ahlaki temelini teşkil eder. Kefalet ise daha ziyade hukuki güvence sağlanması anlamındaki yardımlaşmayı ifade eder ve birbirlerinin kefili olanlar, kredi ihtiyaçlarının güvencesini birbirlerine kefil

50 Poroy/Tekinalp/Çamoğlu (2017), s. 96.

51 Üstün/Aydın, s. 455-457. 
olarak sağlamış olurlar. Kredi ve sigorta kooperatifleri açısından karşılıklı kefaletin önemi daha büyüktür. ${ }^{52}$

Amaç unsuru İslam şirketler hukuku açısından değerlendirildiğinde klasik şirketler içinde kooperatif ile birebir örtüşen bir şirket olmamakla beraber, bu amaca hizmet eden "muvâlat akdi" ve "âkıle sisteminden" bahsedebiliriz. Muvâlât akdi, nesebi belli olmayan kişinin diğer bir kişi ile "ölürse mirasçısı olması, cinayet işlerse de diyetinin onun ve âkilesi tarafından ödenmesi” üzere anlaşma yapmasıdır. ${ }^{53} \mathrm{Bu}$ anlaşma sonucu bir taraf diğer tarafın mali yükümlülügünü üstlenmiş olur. ${ }^{54}$ Bir anlamda mesuliyet sigortası gibi onun zararına kefildir ve "ortak menfaat kapsamında karşılıklı yardımlaşma üzerine sözleşme” olmak noktasında kooperatif ortaklığı ile benzeşmektedir. Bir taraf zararı karşılarken diğer taraf da mirastan faydalanma hakkını elde etmiş olmaktadır. Âkıle sisteminde ise, kasıt unsuru bulunmaksızın bir öldürme veya yaralama hadisesinde suçlunun ödemesi gereken diyeti akrabalarının ödemesidir. ${ }^{55} \mathrm{Bu}$ da bir çeşit yardımlaşmadır. Diyeti ödeyen yakın akrabalar (asabe) aynı zamanda İslam miras hukuku kuralları çerçevesinde mirastan pay alan kimselerdir. ${ }^{56} \mathrm{~Hz}$. Peygamber'in (sav) uygulamasına ${ }^{57}$ dayanan bu sistem bütün fikıh mezheplerince kabul edilmiştir. ${ }^{58}$ Pozitif hukukta âkıle benzeri bir kuruma rastlanmamakla beraber İslam hukukunda risk ve menfaat paylaşımı kapsamında kooperatif ile aynı amaca hizmet ettiği düşünülebilir. Yani, her ikisinde de tarafların karşılıklı risk ve menfaat paylaşımı söz konusudur.

52 Poroy, Reha/Tekinalp, Ünal/Çamoğlu, Ersin (2005) Ortaklıklar ve Kooperatif Hukuku, İstanbul, Arıkan, s. 949.

53 Ebu Ceyb, s. 389.

54 Merginânî, Ebü'l-Hasen Burhânüddîn Alî b. Ebîi Bekr b. Abdilcelîl el-Fergānî (t.y.), elHidâye, İstanbul, Eda, C: 3, s. 274.

55 Bilmen, Ömer Nasuhi (t.y.), Hukukı İslamiyye ve Istılahatı Fıkhiyye Kamusu, İstanbul, Bilmen, C: 3, s. 7; Ebu Ceyb, s. 259.

56 Udeh, Abdu'l-Kâdir (t.y.), et-Teşrîu'l-Cinâî, Beyrut, Dâru'l-Kâtibi'l-Arabî, s. 672-673.

57 İbn Mâce, Ebû Abdillah Muhammed b. Yezid el-Kazvînî (1981), es-Sünen, Çağrı, "Diyât", 15; Nesâî, Ebû Abdurrahman Ahmed b. Şuayb b. Ali b. Bahr b. Sinan b. Dinâr (1981), Sünen-i Nesâî, İstanbul, Çağrı, "Kasâme”, 37.

58 Aktan, Hamza (1989), “Âkıle”, Türkiye Diyanet Vakfı İslam Ansiklopedisi, İstanbul, TDV, C: 2 , s. 248. 
Yukarıdaki uygulamalara ek olarak İslam hukukunda hem Kur'an'da hem de Sünnet'te pek çok delil yardımlaşmayı teşvik eder. Örneğin Kur'an'da; "iyilik ve takva üzere yardımlaşmak" ${ }^{2}$; "Hakkta ve hayırda yardımlaşmak, tavsiyeleşmek" ${ }^{00}$ emredilmektedir. Sünnette de "kim mü’minden bir zorluğu kaldırırsa Allah da kıyamet gününde o kimseden zorluğu kaldıracağı”61, "kul kardeşinin yardımında olduğu sürece Allah'ın da o kulun yardımında olacağ1"62 bildirilmektedir. Diğer bir örnekte Hz. Peygamber (sav); "Eş’arîler, gazvede azıkları azaldığında veya Medine'de aile efradının yiyeceği azaldığında yanlarında ne varsa getirip bir yaygıya dökerler ve bunu bir kapla aralarında eşit olarak paylaşırlar. Bundan dolayı Eş'arîler bendendir, ben de onlardanım" ${ }^{33}$ buyurmaktadır. Burada da kooperatif ortaklığındaki yardımlaşma ve dayanışma ile aynı özden hareket edildiği düşünülebilir. Ayrıca fakihlerin görüşlerinde de kooperatif fikrine benzer şekilde, fertlerin zarar riskinin toplumsal dayanışma, tazmin ve tekâfül yoluyla çözülmesine dair hükümler görebiliriz. Mesela, Karâfi'nin "Gemilerden atılan şeylerin tazmin edilmesi kuralı ile tazmin edilmeyecek şeylerin kuralı arasındaki fark” başlığı altında belirttiği gibi; "eğer korku sebebiyle gemiden bazı yükler atılırsa yükü atılan kimseler yükü atılmayan kimselerin mallarına ortak olurlar. Atılan şey hepsinin kurtuluşuna vesile olmuştur ve nemalanmasında ya da eksilmesinde iltimas geçmeksizin satın alma günkü fiyat üzerinden risk tüm gemidekilere dağıtılır. Çünkü onlar gemiden atılan şeyler vasıtasıyla korunmuş oldular ve adalet atılan malın yükünü (riski) bir kişiye yüklemeksizin tüm gemidekilere dağıtmayı gerektirir. ${ }^{64}$

Netice olarak kooperatiflere "amaç" unsuru açısından bakıldığında İslam hukukunda bunun bir çok örnek ve dayanağını bulmak mümkündür. Yani bir sözleşmede temel unsurlardan biri "karşılıklı yardım-dayanışma"

59 Mâide, 5/2.

60 Asr, 103/3.

${ }^{61}$ Buhârî, "Mezâlim”, 3; Müslim, Ebu'l-Huseyin Müslim b. Haccâc (1981), el-Câmiu'sSahîh, İstanbul, Çağrı, "Birr”, 58.

62 Müslim, "Zikr”, 38; İbn-i Mâce, "Mukaddime”, 17.

63 Buhârî, "Şirket”, 1; Müslim, "Fezâilü’s-Sahâbe”, 16.

64 Karâfî, Ebü'l-Abbâs Şihâbüddîn Ahmed b. İdrîs b. Abdirrahmân el-Misrî (2010), Envârü'l-Burûk fî Envâ' i'l-Furûk, Kuveyt, Dâru'n-Nevâdir. C: 4, s. 8. 
olabilir ve hatta bu teşvik edilmiştir. Ancak şunu da belirtmekte fayda var; sadece amaç unsuru, bir ortaklı̆̆1 uygun görmek için yeterli değildir. $\mathrm{Bu}$ ortaklığın bir bütün olarak değerlendirilip tüm unsurlar açısından bir uygunluğun olması şartı aranır. Uygun olmayan unsurlar içeriyor ancak birey ve toplumun ihtiyacı olan bir kuruluş ise, yeniden yapılandırılması yoluna gidilebilir.

\section{Serbest Katılma ve Çıkma Unsuru}

Kooperatif, katılımcılarının meslek ve geçimlerine ait ihtiyaçlarını gidermek ve ekonomik çıkarlarını korumak üzere kurulmuş ortaklık olması sebebiyle (Koop.K, md. 1) korunmak ihtiyacı duyan kişilere kapılarını kapatamaz. "Açık kapı ilkesi” olarak da ifade edilen bu özellik kooperatifin hukuki niteliğini belirlemede en önemli unsurlardan biridir. 1995 yılındaki Uluslararası Kooperatifler Birliği (ICA) Kongresi'nde kabul edilen Kooperatif Kimlik Bildirgesi'nde; "gönüllü ve herkese açlk ortaklık" şeklinde ifade edilen ilkeye göre; "etkinliklerine katkıda bulunabilecek ve bu etkinliklerinden yararlanacak tüm kişilerin cinsel, sosyal, ırksal, siyasal ve dinsel ayırımcilık olmaksızın, hizmetlerinden yararlanabilecek ve ortaklığın sorumluluklarını kabule razı olan herkese ${ }^{365}$ kapılarını açık tutması benimsenmiştir. Sermaye şirketlerinin genelinde olduğu gibi kapalı ortaklı bir yapıda olmayıp yapı kooperatifleri istisna olmak üzere değişir ortaklı ve değişir sermayeli bir özeliğe sahiptir (Koop.K, md. 1,8,10). Diğer şirket türlerinde azami pay sayısı kadar ortak bulunabilirken bu özelliği gereği ortak sayısı anasözleşmeyle sinırlandirilamaz.

Gönüllü olarak ortaklığa katılmak isteyen herkese açık kapı olması ve istendiği zaman ayrılma imkânın mevcudiyeti beraberinde değişir ortaklı ve değişir sermayeli bir yapıyı getirmektedir. Kooperatif anasözleşmesinin gereği olarak başlangıçta kabul edilen bu şartlar tüm ortakları bağlayıcıdır.

65 T.C. Ticaret Bakanlığı, "Kooperatifçilik İlkeleri”, <https://ticaret.gov.tr /kooperatifcilik/kooperatifler-hakkinda-bilgiler/kooperatifcilik-ilkeleri> s.e.t. 20.07.2020; Dalkıran, Gülüm Burcu (2017), "The Support of Women Work within Cooperative Enterprises: Sample of Turkey”, Social Sciences Research Journal, C: 6, S: 3, s. 3. 
Konu İslam hukuku açısından tahlil edildiğinde; "akit serbestisi” kapsamında şirketin konusunun meşru olması ve işletmesinin meşru muamelelerle yürütülmesi kaydı ile akit yapabilme ehliyetini haiz herkese; "cinsel, sosyal, irksal, siyasal ve dinsel ayırımcllk olmaksızın" ortaklık kapısının açık tutulması şartı getirilebilir. Bu şart anasözleşmeyi kabul eden herkes için bağlayıcıdır.

\section{Ortak Unsuru}

Kooperatife gerçek kişiler ve bazı tüzel kişiler ortak olabilirler ${ }^{66}$ ancak kooperatiflerin temeli insan unsuruna dayanmaktadır. Kooperatifi oluşturan insanların dayanışması ve birbirine olan güveni diğer ortaklıklara göre çok daha üst seviyededir. Kooperatifler Kanunu'nda kooperatif tanımlanırken (Koop.K, md. 1) “ortak” sözcüğü yer almıştır. Bu sözcük, kooperatiflerdeki insan unsurunun şahıs ve sermaye şirketlerindeki gibi olabileceğini düşündürse de Kanunun bazı maddelerinde "ortak", bazı maddelerinde ise “üye” sözcügü kullanıldığı görülür (Koop.K, md. 10, 14/1, 17). Bu farklı kullanım, kooperatiflerin hukuki niteliğine ilişkin tartışmaları artıran sebeplerden biri olarak kabul edilmektedir. ${ }^{67}$ Kooperatif için "ortak" sözcügünün kullanımı onu "sermaye şirketi” yapmayacağı gibi “üye” sözcügüüün kullanımı da ticari menfaat gütmeyen kuruluşlar (vakıf, dernek, sendika, vd.) statüsünde göstermek için bir sebep olmayacaktır.

Kooperatiflerde "kişi" unsuru birinci sırada, "pay" ikinci sırada gelirken sermaye şirketlerinde "sermaye" birinci sırada, "kişis" unsuru ikinci sırada gelir. Kooperatifler, kişiyi merkeze alarak ortaklarının menfaatini dürüstlük çerçevesinde korumak için çalışır. Ortakları koruma kapsamında zaman zaman üretilen mal maliyet fiyatına ortaklara verilir, üretici ile tüketici arasındaki yol kısaltılarak hem ortaklar hem de kamu menfaat elde eder. ${ }^{68}$

İslam hukuku açısından bakıldığında bir ortaklığın temelinin insan unsuruna, ortakların birbirine yardım ve güven esasına dayanması mümkündür. Hatta bu yapı İslam hukukunun temel kaynakları tarafından

\footnotetext{
66 Poroy/Tekinalp/Çamoğlu (2005), s. 949.

67 Mollaoğlu, s. 105, 126.

68 Mollaoğlu, s. 108.
} 
teşvik edilmiştir. Bu yönde "hayırda yarış", "iyilikte yarış", "insanların zorluklarını gidermek" ve "dayanışma" konularında pek çok ayet ve hadis bulunmaktadır. ${ }^{69}$

\section{Tüzel Kişilik Unsuru}

Tüzel kişilikler sosyal ihtiyaçların bir sonucu olarak ortaya çıkmıştır. Kanunda (TMK.md. 47) "başlı başına bir varlığı olmak üzere örgütlenmiş kişi toplulukları ve belli bir amaca özgülenmiş olan bağımsız mal toplulukları, kendileri ile ilgili özel hükümleri uyarınca tüzel kişilikler kazanırlar"70 hükmüne yer verilerek pozitif hukuk düzeninde, tüzel kişiliklere kendisini oluşturan gerçek kişilerin iradeleri dışında farklı bir irade gücü verilmiştir.

Tüzel kişiler; kamu hukuk tüzel kişileri, özel hukuk tüzel kişileri ve kamu iktisadi kuruluşları olmak üzere üç grupta incelenmektedir. Kooperatif, özel hukuk tüzel kişiliğini haiz bir kişi birliğidir. ${ }^{71}$ Kooperatifin tüzel kişiliği ve hak ehliyetini kazanması ticaret siciline tescili ile başlar. Kooperatiflerin şubeleri de merkezin sicil kaydına atıf yapmak suretiyle bulundukları yerin ticaret siciline tescil olunurlar (Koop.K, md. 3).

Kooperatifler, bütün hakları iktisap ve borçları ilzam etme ehliyetini haiz olup (TMK md. 48), tüzel kişilik kazandıkları andan itibaren hak ve borçlara ehil olurlar (Koop.K, md. 33). Kooperatifler aynı şekilde, kuruldukları andan itibaren fiil ehliyetine de sahip olur. Kooperatif fiil ehliyetini organları ve temsile yetkili olanlar eliyle kullanır ve bu kimseler tarafından üçüncü kişilere karşı temsil edilebilir. Hak ehliyetinin gereği olarak üyelerden aidat isteyebilir ve üyeleri çıkarma hakkını kullanabilir. Gerekli organlara sahip oldukları andan itibaren de fiil ehliyetini kullanabilir.

69 Mâide, 5/2; Asr, 103/3; Buharî, "Edeb" 27, "Mezâlim”, 3; Müslim, “Birr”, 6, 58; Beşer, s. 229.

70 Topal, Cemre/ Kalaycı, Filiz (2007), Gerekçeli-Notlu Türk Medeni Kanunu, Ankara, Bilge, s. 28-29.

71 Poroy, Reha/Tekinalp, Ünal/Çamoğlu, Ersin (2010) Ortaklıklar ve Kooperatif Hukuku, 12. Baskı, İstanbul, Vedat Kitapçılık, s. 112. 
Kooperatiflerin tüzel kişilik oldukları konusunda Yargıtay kararlarında tam bir tutarlılık görülmekle beraber tacir olup olmadıkları veya davanın ticari sayılıp sayılmayacağı konusunda farklı kararlar bulunmaktadır. ${ }^{72}$

İslam hukuku açısından kooperatiflerin "tüzel kişilik unsuru" incelendiğinde; tüzel kişiliğin kabulüne dair bir problem yoktur. Tüzel kişi gerçek kişi gibi haklara ve yükümlülüklere sahiptir. İslam hukukunun doğuşundan itibaren gerçek kişilerin dışında tüzel kişi olarak haklara sahip olmanın (ilzam) ve borç altına girmenin (iltizam) mümkün olduğu örneklere rastlamak mümkündür. Bu kavram, klasik eserlerimizde daha ziyade "hükmi şahıs” olarak yer almış kabul görmüştür. Örneğin, devlet başkanı ve idarecilerin fiillerine dair birçok hüküm ancak devletin hükmi bir şahsiyet olarak kabul esasına dayandırılarak açılanabilir. Ayrıca beytülmalin de tüzel kişilik olarak kabul edildiğini görmekteyiz. Zira beytülmal kamunun mallarında milleti temsil vasfı ile alacaklı, borçlu, mâlik sıfatlarına ve mirasçısı bulunmayan kimsenin terekesine sahip olabilmektedir. Bütün bunlar beytülmalin hükmi şahsiyet/tüzel kişilik olması sebebiyle mümkün olmaktadır. Aynı şekilde vakfın da tüzel kişi olarak haklara ve yükümlülüklere sahip olduğu görülmektedir. Vakıf diğer kişilerle satış, kira, istibdâl gibi hukuki muameleler yapabilmektedir. Netice olarak kooperatif "tüzel kişilik" olarak hukuki işlemlere taraf olabilir. ${ }^{73}$

Klasik İslam hukuku literatüründe tüzel kişiliğin "kamu hukuku tüzel kişisi” ya da "özel hukuk tüzel kişisi” kapsamında değerlendirilmesine rastlanmamakla beraber bu tür bir ayrıma gitmenin önünde bir engel de görülmemektedir. İslam hukukunu günümüz pozitif hukukuna muadil bir ayrıma tabi tuttuğumuzda kooperatifi “özel hukuk tüzel kişisi” içinde değerlendirmek uygundur.

Mollaoğlu, s. 120.

73 Karaman, Hayrettin/Özdemir, Ahmet (2019), Fıkhi Bilgi ve İlişkiler Iş̧ı̆ında Eşya ve Şahsın Hukuku, İstanbul, Kitabi, s. 183-188; Dönmez, İbrahim Kâfi (2010), "Şahıs", Türkiye Diyanet Vakfı İslam Ansiklopedisi, İstanbul, TDV, C: 38, s. 271-272; Köse, Murtaza (1998), “İslam Hukuku Ve Modern Hukuka Göre Tüzel Kişilik”, Ekev Akademi Dergisi, C: 1, S: 2, s. 229-230. 
İslam hukukunda özel hukuk tüzel kişisinin "tacir nitelemesi” konusuna gelince; en geniş anlamıyla, ticaretle uğraşan, bir ticari işletmeyi kısmen dahi olsa kendi adına işleten kimseye "tacir" nitelemesinin yapıldığg ${ }^{74}$ göz önünde bulundurularak gerek gerçek kişi gerek özel hukuk tüzel kişisinin "tacir” olarak nitelenmesinde bir sakınca görülmemektedir. $\mathrm{Bu}$ nitelendirmenin imkânına örnek olarak İslam hukuk tarihi kaynaklarında beytülmalin tüzel kişilik olarak ticari muameleler kapsamında ortaklıklar yaptığ ${ }^{75}$ ve vakıfların ticari işletmeler işlettiği gösterilebilir. ${ }^{76}$

İslam hukuku açısından tüzel kişilik olan kooperatife bir başka tüzel kişinin ortak olması mümkündür. Günümüz kooperatif hukuku çerçevesinde gerçek ve tüzel kişiler tarafından kooperatif kurulabileceği ${ }^{77}$ gibi, kurulmuş bir kooperatife faaliyet alanı ile ilişkili ise bir anonim şirket de tüzel kişi ortak olarak katılabilir. İslam hukukunda tüzel kişi statüsünde değerlendirilen şirket gerçek kişi gibi hareket edebilir. Ülkemizde, bir üretim kooperatifi ile şirketin el ele vermesinden meydana gelen sinerjiyi göstermesi bakımından "Konya Pancar Ekicileri Kooperatifi” güzel bir örnektir. Bir üretici kooperatifi olarak 900 bin çiftçiyi arkasına almış, 1 fabrikadan başlayıp 20 yılda 45 fabrikaya kadar çıkmış ${ }^{78}$ tek üretim çeşidinden binin üzerinde mamul ürüne doğru

74 T.C. Adalet Bakanlığı Hukuk Sözlüğ̈̈u, “Tacir” < https://sozluk.adalet.gov.tr/tacir> s.e.t. 20.08.2020.

75 İbn Kudâme, Ebu Muhammed Muvaffakuddin Abdullah b. Ahmed b. Muhammed (1992), el-Muğni, Beyrut, Dâru’l-Fikr, C: 5, s. 135; Habergetiren, Ömer Faruk (2005), "İslam Hukuku'nda Sermaye ve Sermaye Hareketleri" (Doktora) Harran Üniversitesi Sosyal Bilimler Enstitüsü, s. 95-96.

76 Kelebek, Mustafa (2015), İslam Vakıf Hukuku ve Sivas Dâru'ş-Şifâ Vakfiyesi, İstanbul, Ravza, s. 69; Kurt, İsmail (2020), "Şer’î Açıdan Vakıf ve Vakıfların Muhasebe Usulü", İSAV, <http://www.isav.org.tr/img/20131029_506250263.pdf > s.e.t. 15.08.2020.

77 Koop.K, md. 1'de 5146 sayılı Kanunla yapılan değişiklikle mümkün olabilmiştir. Mollaoğlu, s. 110.

78 Torku, “Kooperatifçilik Bizim İçin Seçenek Değil Mecburiyettir", <http://torku.com.tr/tr/haber/detay/10140/kooperatifcilik-bizim-icin-secenek-degil-mecb> s.e.t. 20.08.2020; Torku "Tarihçe", <http://torku.com.tr/tr/icerik/detay/170/tarihce> s.e.t. 20.08.2020. 
genişleyerek "ulusal bir marka" ile de örnek bir çıkış sergilemiş ve tüm ortakların yararına bir sonuç meydana getirmiştir. ${ }^{79}$

\section{Unvan Unsuru}

Kooperatiflerin insan unsuru "ortak" veya "üye" sözcükleri ile ifade edildiği gibi kooperatifler kendisi için de genellikle "unvan” sözcüğü kullanılmakla birlikte “ad” sözcüğü de kullanılmıştır (Koop.K, md.2/3, 4/1, $85 / 3$ ). Kurulan ortaklığın türünü göstermek üzere kooperatifin adı olarak da ifade edilebilecek olan unvanda "kooperatif" sözcügünün yer alması zorunludur (TTK. md. 43).

Kooperatif unvanları genellikle "işletme konusu" ve "kooperatif" sözcügünden oluşur. Kooperatifin konusu ve kooperatif sözcükleri unvanın çekirdek kısmını oluşturur. Unvanlarda çekirdek kısmı kullanıldıktan sonra ek kullanılması zorunlu değildir. Ek kullanıldığında unvanın bir parçası olur ve hukuki koruma altındadır. ${ }^{80}$ Mesela, "Pak Evler (ek) Yapı Kooperatifi (çekirdek)" gibi. Unvanda işletme konusu yerine gerçek bir kişinin adı ve soyadı yer almamalıdır. Ek kısmında gerçek kişinin adı ve soyadı yer alması durumunda kooperatif kelimesi "Koop." şeklinde kısaltılamaz (Koop.K, md.2/3, 4/1, 85/3). Ayrıca kooperatiflerin ve üst kuruluşlarının unvanlarında kamu kurum ve kuruluşlarının isimlerine yer verilemez. ${ }^{81} \mathrm{Bu}$ şart bir anlamda kooperatif şirketinin ayrıştırıcı unsurudur. Böylece unvanında "kooperatif" sözcügü yer alan bütün kuruluşlar ilgili kanunun şartlarına tabi olur.

İslam hukuku açısından şirket unvanında ilgili şirket çeşidinin sözleşmeye yazılması şartı konulabilir. Bu uygulamanın benzerini "mufâvada" şirketinde görmek mümkündür. Mufâvada şirketinde sözleşme "mufâvada" sözcügünün kullanılmasıyla ya da mufâvada içeriğini ifade eden lâfızla yapılma şartı vardır. ${ }^{82}$ Mufâvada şirketi olarak kurulan ortaklık yapısı ilgili

79 Konya Şeker, “Türkiye'nin Üreten Gücü”, <http://www.konyaseker.com.tr/tr/icerik/detay /2113/konya-seker> s.e.t. 20.08.2020.

80 Mollaoğlu, s. 123.

81 Poroy, Reha (1991), Ticari İşletme Hukuku, 6. Baskı, İstanbul, Beta, s. 216; Mollaoğlu, s. 124.

82 Mergınânî, s. 4; Serahsî, s. 154. 
şartlardan birini ya da bir kaçını yitirirse "mufâvada şirketi niteliği"ni kaybeder.

Şirketlerin tamamında ortaklık temelinde ortak yönler olmakla beraber her şirket çeşidinin ayrıştırıcı özellikleri de bulunabilir. Bu ayrıştırıcı özelliği ifade eden sözcügün bulunmaması muâmelatta anlaşmazlıklara yol açma potansiyeli taşıyorsa "ilgili şirketin kendine has özelliğini belirten ayrıştırıcı sözcügün” şirket çeşidi olarak unvanda yer almasının İslam hukuku açısından şart koşulmasında şirket oluşumu için bir engel görülmemektedir. Özellikle böyle bir şart konularak ileride muhtemel anlaşmazlıkların önüne geçilmiş olur.

\section{Sermaye (Malvarlığı) Unsuru}

Kooperatifin amacı, niteliği ve yapısı dikkate alındığında diğer ortaklık çeşitlerinden ayıran en önemli özelliğinin "değişir ortaklı” ve "değişir sermayeli" oluşu olduğu görülmektedir. Asıl unsur "insan” ve yardımcı unsur "sermaye" olarak varlığını sürdürmektedir. Sermayenin gerekli olduğu Kooperatifler Kanunu'ndaki tanımda yer alan "parasal katkı" (Koop.K., md. 1) ve "Kooperatife giren her şahıstan en az bir ortaklık payı alınması gerekir" ifadelerinden (Koop.K., md. 19) anlaşılmaktadır. Asıl unsuru "sermaye" olan şirketlerden farkı, az da olsa sermaye ve mutlaka "kişi”nin gerekli oluşudur. Dolayısı ile kooperatiflerde sermaye ikinci derecede önemli bir unsurdur. Kanun gereği, az da olsa ortakların parasal katkı yapmaları beklenmektedir. $\mathrm{Bu}$ durum, "iş gücü” ve "parasal katkı", kooperatifin "kişisellik” yönünü ve "sermayeyi” öngördügüüü kanıtlar. ${ }^{83}$ Kooperatiflerde "sermaye"nin zorunlu

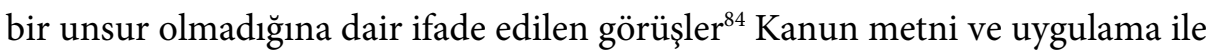
örtüşmemektedir.

Uygulamada kooperatif anasözleşmesine sermaye olarak kooperatifin kuruluşundaki üye sayısı ile kooperatif ortaklık pay değeri çarpılarak elde edilen rakam yazılır. Bu durumda sermaye, kooperatifin mal varlığının değerini ifade eder. Kooperatife para olarak "nakdî sermaye" ve mal olarak "aynî sermaye" getirilebilir. Sermaye şirketleri amaçlarına salt "sermaye"yi

83 Poroy/Tekinalp/Çamoğlu (2005), s. 949; Mollaoğlu, s. 127.

84 Mollaoğlu, s. 124. 
kullanarak ulaşmaya çalışırken kooperatifler de "yardımlaşma”, “dayanışma”, "parasal katkı" ve "kefalet"i kullanarak ulaşmaya çalışır. Yani hem sermaye hem de iş gücü birlikte aktif olarak kullanılmaktadır. Yapı kooperatifleri dışındaki diğer kooperatiflerde sermaye ve pay sayısı, ortak sayısı ile doğru orantılı olarak değişir. Sermayedeki bu değişken yapı onu anonim ortaklıklardan ayıran önemli özelliklerden biridir. Bu durumu ifade etmek üzere Kooperatifler Kanunu'nda “sermaye miktarı sınırlandırılarak kooperatif kurulamaz” hükmü getirilmiştir (Koop.K, md. 2/3). Kural olarak anonim ortaklıklarda "sermayenin belirliliği ve korunması ilkesi" gereği ortaklara şirketten çıkma hakkı kısıtlanmış, onun yerine serbest pay devri ilkesi benimsenmiştir. Kooperatiflerde ise kooperatife bilgi verilerek payların başkasına devri mümkündür, ancak ortaklık payları ve ortaklık senetleri serbest piyasada hisse senedi gibi satılamaz. ${ }^{85}$

Kooperatiflerin ortaklık sözleşmesinin "mal/sermaye” unsuru olarak değerlendirilen "ortaklaşa yardımlaşma içeren emek ve nakdi-ayni sermaye"si üzerine kurulabilme imkânı vardır. İslam şirketler hukuku kapsamında kurulacak bir şirketin konusu bakımından incelendiğine bir şirketin mal, emek veya itibar esası üzere kurulduğu görülmektedir. ${ }^{86}$ İslam hukukunun doğuşundan itibaren isimli akitler kapsamında sadece emek üzere kurulan, sadece sermaye üzere kurulan ya da emek ve sermaye üzere kurulan ortaklık örnekleri mevcuttur. Şirket sözleşmesi çerçevesinde tarafların sadece emeklerini koyarak oluşturdukları "şirket-i a’mâl”, mallarını ortaya koyarak oluşturdukları "şirket-i emvâl” ve itibarlarını, ticari kredilerini ortaya koyarak oluşturdukları "şirket-i vucûh" geçmişten günümüze uygulama alanı bulmuştur. Ayrıca hem emeğin hem de sermayenin ortaya konulması sonucu "emek-sermaye ortaklığı" kapsamında kurulan "mudârabe”yi de örnek olarak verilebiliriz. Mudârabe şirketinde tarafların "emek" ve "sermayesi/malı" bir araya getirilmesine benzer bir şekilde kooperatifte de "ortakların tamamının emeği ve mali katkısı"nın bir araya getirilmesi söz konusudur. ${ }^{87}$ Dolayısı ile

\footnotetext{
85 Mollaoğlu, s. 127. “Şirket”, Türkiye Diyanet Vakfı İslam Ansiklopedisi, İstanbul, TDV, C: 39, s. 199.

87 Zuhaylî, s. 836-837; Gözübenli, s. 199-200.
} 
kooperatifte konusu bakımından yardımlaşmaya dayalı olarak "ortakların emeği” ve "mal” üzere kurulu bir ortaklık şekli söz konusudur. İslam hukuku açısından böyle bir ortaklığın meşru bir işletme konusu olması şartıyla kurulmasında bir sakınca görülmemektedir. Ancak şirket "yardımlaşmaya dayalı ortakların emeği ve mal” üzere kurulmakla beraber garar, cehâlet, ribâ ve kumar gibi özellikleri taşıyacak şekilde kurulması halinde İslam hukuku açısında caiz görülmez. ${ }^{88}$

\section{Eşitlik ve Demokratik Yönetim Unsuru}

Kooperatifler Kanunu'nun kabul ettiği esaslara göre ortaklar hak ve vecibelerde eşittir (Koop.K, md. 23). Bu eşitlik "mutlak” ve "nisbi” olmak üzere iki şekilde değerlendirilebilir.

Mutlak eşitlik, kooperatiflerde ortakların yaptıkları katkı payına ve sermaye katılım payına bakılmaksızın her ortağın eşit olması anlamına gelir. $\mathrm{Bu}$ kapsamda her ortağın sadece bir oy hakkı vardır (Koop.K, md. 48). Aynı koşullardaki ortakların hepsi aynı hak ve borçlara sahip olup kurallar herkese aynı şekilde uygulanır. ${ }^{89}$ Bu yönüyle diğer şirketlerden ayrılmaktadır. Sermaye şirketlerinde her pay bir oy hakkına karşılık geldiği için pay senetlerinin yarısından fazlasına sahip olan kimse şirketin yönetimine tek başına sahip olabilir. Ancak bazı kararların alınması ağırlaştırılmış nisaplara tabidir. $\mathrm{Bu}$ durum kooperatiflerde söz konusu değildir.

Nisbi eşitlik ise, ortakların kooperatif ile olan ilişki düzeylerine göre, her ortağın yaptığı iş ve işlemin ayrı ayrı değerlendirilerek hesaplanması demektir (Koop.K, md. 38). Yani her ortak kooperatifle olan ilişkisi nispetinde, farklı durumları göz önüne alınarak belirli bir ölçüye göre menfaat elde eder. ${ }^{90}$ Mesela ortağın; bir tüketim kooperatifinde alış-veriş yapması, motorlu taşıtlar kooperatifinde taşıma yapması, tarım satış kooperatifinde ürün teslim etmesi ile doğru orantılı olarak olumlu gelir farkından faydalanır. ${ }^{91}$

\footnotetext{
88 Karaman, Hayrettin (2012), İş ve Ticaret İlmihali, İstanbul, İz, s. 231; Beşer, s. 226; Yaman/Çalış, s. 292-296.

Mollaoğlu, s. 131.

Üstün/Aydın, s. 122-123.

1 Üstün/Aydın, s.130-131.
} 
Kooperatiflerde yönetenler ve yönetilenler şeklinde bir sinıflandırma söz konusu değildir. Kooperatif ortakları yöneticileri seçebilir, seçilmiş olan yöneticileri eleştirebilir ve hatta onların değiştirilmesini sağlayabilir.

İslam hukuku açısından; ortakların yaptıkları katkı payına ve sermaye katılım payına bakılmaksızın her ortağın eşit olması, her ortağın sadece bir oy hakkının olması ve ortaklık menfaatinden kooperatifle olan ilişkisi nispetinde belirli bir ölçüye göre faydalanması şartı ile bir şirket kurulmasında bir sakınca görülmemektedir. Mufâvada şirketinde "mufâvada" sözcüğü zikredilerek daha başlangıçta bu şirket çeşidinin şartlarının taraflarca kabul edilmesi gibi kooperatif şirketinde de "kooperatif" sözcügünün unvanda yer alması şart koşularak taraflar ilgili kanundaki şartları kabul etmiş sayılır. Böylece bu şirket ile ortaklık kurulmuş olur. Kooperatifin temel unsurlarından biri olarak şirketin ortaklar arasından seçilen bir heyet tarafından yönetilmesi mümkündür.

Kooperatif unsurları açısından genel olarak değerlendirildiğinde İslam hukukuna göre bir problem görülmemektedir. Yukarıdaki unsurları çerçevesinde; kâr amacı öne çıkmaksızın, "karşılıklı yardımlaşma, kefalet ve beraberinde ortakların menfaati” önceliklenerek risk-menfaat paylaşımı esası üzere kurulu; gönüllü ve herkese açı; gerçek ve tüzel kişilerin ortak olabildiği; tüzel kişiliği haiz; unvanda "kooperatif" sözcüğünü geçmesinin zorunlu olduğu; değişir ortaklı ve değişir sermayeli olarak her ortağın yönetimde eşit haklara sahip olduğu (mutlak eşitlik), ortakların kooperatif ile olan ilişki düzeylerine göre, her ortağın yaptığı iş ve işlemin ayrı ayrı değerlendirilip hesaplanarak menfaat elde ettiği (nisbi eşitlik) ilkeleri benimseyen bir ortaklık sözleşmesi mümkündür. Aşağıda ise böyle bir ortaklığı İslam hukukuna göre kuruluş ve sıhhat şartları açısından değerlendirmeye çalışacağız.

\section{B. KOOPERATIF ORTAKLIĞININ AKDİN KURULUŞ VE SIHHAT ŞARTLARI AÇISINDAN TAHLILLI}

Pozitif hukuk çerçevesinde kooperatif ilkeleri İslam hukuku ile ilişkilendirilerek incelendiğinde uygun görülmekle beraber uygulamadaki kooperatif ortaklığının İslam akit teorisi kapsamında akdin kuruluş ve sıhhat şartları bakımından da tahlil edilmesi gereklidir. Zira gerekli ilkeleri taşımasına rağmen bir sözleşme kuruluş ve sıhhat şartlarında eksiklik taşıyorsa 
İslam hukuku açısından batıl ya da fasit olarak nitelendirilir ve uygulama alanı bulamaz.

Akdin kuruluş (in’ikâd) şartları açııından ele aldı̆̆ımızda; Kooperatifin tarafları, kooperatif ortakları, gerçek ve tüzel kişiler olarak sözleşme ehliyetini kazanmış kişilerdir. Yukarıda "tüzel kişi”" unsurunda açıklandığı üzere hak ve fiil ehliyetini haiz gerçek ve tüzel kişilerin ortaklık tarafları olarak yer alması İslam hukuku açısından uygundur.

Kooperatifin konusu; tarafların ortaklık işletme konusu ile ilgili olarak ortaya koydukları iş gücü/emek, sermaye ve karşılıklı kefilliktir. Bunların ayrı ayrı ya da hepsi bir arada sözleşme konusu olması mümkündür. Ancak kooperatifin unvanında belirtilen "işletme konusu" İslam hukukunun uygun gördüğü meşru işletmelerden olmakla sinırlıdır. Örneğin "domuz ürünleri" üzerine kurulan bir işletme ya da "İslam hukukunun gayrimeşru saydığ 1 iş ve işlemlerin yapıldı̆̆ı bir tatil köyü işletmeciliği” üzerine kurulan bir kooperatif uygun görülmez.

Konuya tarafların rrzası (icab-kabul) açısından bakıldığında ise, kooperatif anasözleşmesi yazılı bir irade beyanı ile gerçekleşmekte, örneğin bir kişi, kurulmuş olan bir kooperatife, anasözleşmenin ortaklar için öngördüğü şartları, hak ve borçları kabul ettiğini beyan etmek (icap) ve bu talep ortaklık yönetimi tarafından kabul edilmekle (kabul) ortak sıfatını kazanır. Kooperatiflerin kuruluşu bakımından bu konuda bir problem görülmemektedir.

Kooperatif ortaklığında sadece karşılıklı kefillikten kaynaklanan bir risk paylaşımı söz konusu olmayıp aynı zamanda ortakların kendi aralarında seçtikleri kooperatif yönetimi, iş gücü/emek ve finansal katkı da söz konusu olduğu için geleneksel/yerleşik şirket yapısından farklıdır.

Kooperatif ortaklı̆̆ın akdin sıhhat şartları (ikrah, cehâlet, garar ve fasit şart) açısından incelediğimizde; gönüllülük esası üzere kurulan ve ortakların hür iradeleri ile gerçekleșen bir sözleşme olduğunda dolayı "ikrah" ile maluliyet söz konusu değildir.

Kooperatif anasözleşmesi çerçevesinde ortaklar; iş gücü, belirli bir parasal katkı ve ortaya çıkan risklere karşı tazmin sorumluluğunu (birbirlerine 
kefil olma mükellefiyetini) ortaya koymaktadırlar. Dolayısı ile akdin konusu ve bedeli bakımından bir "bilinmezlik" (cehâlet) söz konusu değildir. Kooperatif sözleşmesinin emek-sermaye ve kefaletten mürekkep bir yapısı vardır. Anasözleşmede aksine bir şart kabul etmedikçe ortakların sorumluluğu sadece ortaklık payı oranıla sınırlıdır. Ancak kooperatif ortaklarının daha fazla sorumluluk almak istemeleri halinde anasözleşmede açıkça belirtmek şartıyla kanunda (Koop.K. md. 51, 52) düzenlenmiş olan sınırsız sorumluluk kapsamında mal varlıklarının tamamı ile sorumlu olacakları tazmin sorumluluğunu da üstlenebilirler. ${ }^{92}$ Netice olarak bir "cehalet" söz konusu değildir.

Bu sözleşmede "garar" yani ortaklar için haksız kazanca yol açacak ölçüde kapalılık açısından incelendiğinde, "sınırlı" ve "sınırsız" sorumluluk göz önüne alınarak iki durum söz konusudur. "Sinırlı sorumluluk" durumunda ortakların yapacakları mali katkıların sınırları belirlenmiştir ve sorumlulukları taahhüt ettikleri paylarla doğru orantılıdır. Yani zarar olduğunda her ortak taahhüt ettiği paylar oranında sorumludur. Bu durumda tarafları anlaşmazlığa ve husumete götürecek seviyede bir belirsizlik söz konusu değildir. Kooperatif anasözleşmesini "sınırsız sorumluluk” şartı ile de kurmuş olsa da "haksız kazanca yol açacak ve tarafları anlaşmazlığa götürecek ölçüde kapalılık”tan söz etme imkânı yoktur. Zira, “mutlak kefâlet”te sınır belirtmeksizin kefil olunabildiği gibi ${ }^{93}$ burada da zarara gerçekleştiğinde herhangi bir sınır koymaksızın zarara müşterek kefâlet söz konusu olmaktadır. Kişi hür iradesi ile tüm mal varlığı ile kefil olma iradesini gösterebilir. Zarar gerçekleştiğinde ortak, payına düşen zarardan tüm mal varlığı ile sorumlu olur. Bu durumda, tazmin edilecek miktar "âkıle" sisteminde olduğu gibi, risk paylaşımı ile kabul edilebilir sınırlarda kalmaktadır ve taraflar menfaatte ortak oldukları gibi zararda da ortak olmak açısından eşittirler.

92 Mollaoğlu, s. 72-86.

93 Kahraman, Abdullah (2008), İslam Borçlar Hukukunda Kefâlet Sözleşmesi ve Günümüzdeki Tatbikatı, İstanbul, M.Ü. İlahiyat Fakültesi Vakfı, s. 176; Karaman, Hayrettin (2013), Mukayeseli İslam Hukuku, İstanbul, İz, C: 2, s. 536. 
Kooperatif sözleşmesinde kumar özelliği de yoktur, zira kumarda bir taraf kazanıyorken diğer tarafın kaybetmesi üzerine kurulu bir risk düzeni vardır. Ancak kooperatifte tüm tarafların menfaatte ve riskte ortak paylaşımı esastır.

Kooperatif sözleşmesini fasit şart açısından incelediğimizde; İslam hukukunun meşru saydığg konularda olmak kaydıyla kooperatif sözleşmesinin taraflarından sadece bir kısmına yarar sağlayan, bedellerin belirsizliği sebebiyle anlaşmazlığa sebep olan, hukuk düzeninin yasakladığı bir şey içeren, sözleşmenin içeriğine ve amaçlarına, yerleşik uygulamalara aykırılık taşıyan şartlara rastlamamaktayız. Faiz yasağı açısından incelendiğinde ise, bedeller iki ayrı cins olan mali katkı ile tazmin arasında olduğu için cins birliğinden kaynaklanacak faiz (ribâ) ihtimâlinden de söz edilemez. ${ }^{94}$

İslam hukuku açısından kooperatiflerin unsurları, kuruluş ve sıhhat şartlarını tahlilinin yanında muâvazalı oluşu ve bağlayıcılığı açısından da tahliline ihtiyaç vardır. Zira bazı İslam hukukçuları tarafından özellikle ticari olarak işletilen sigorta kooperatiflerinin garar, cehâlet ve kumar gerekçesi ile İslam hukukuna uygun olmadığı ifade edilmektedir. Ancak bu kooperatifler ticari olmaktan çıkıp yardımlaşma ve teberru amaçlı olursa caiz görülmüştür. Kooperatifleri muâvza niteliği ve bağlayıcılık açısından aşağıdaki şekilde tahlil edebiliriz.

\section{KOOPERATİFTE MUÂVAZA NITTELİĞİ VE BAĞLAYICILIK}

Kooperatif, karşılıklı bedellerin ödendiği (ivazlı) bir sözleşme üzerine kurulmaktadır. Zira taraflar sözleşme gereği, emeklerini ve mali ödemeleri ortaya koymalarının yanında birbirlerinin kefili olma sorumluluğunu da üstlenmektedirler. Olumlu gelir-gider farkından belirli bir ölçüye göre tüm ortaklar menfaat elde ettiği gibi "olumsuz gelir gider farkı" da ortağa düşen pay hesap edilerek kedisine yapılacak iadeden düşülür. Menfaatte paylaşım olduğu gibi zararda tüm ortaklar dayanışmanın gereği olarak kooperatif kapsamında gerçekleşen zararı tazmin etmiş olurlar.

Sözleşme yapıldığı andan itibaren aidat ödeme, yardımlaşma-emek ve kooperatifin olumsuz gelir gider farkını karşılamak üzere kefillik söz

\footnotetext{
94 Hacak (2006), s. 40.
} 
konusudur. Kooperatif üyesi, sözleşme yapıldıktan sonra sözleşme konusu ile sınırlı olmak üzere kooperatifin himayesi altındadır. 1163 sayılı Kooperatifler Kanunu çerçevesinde düşündüğümüzde ortaklar karşılıklı olarak üstlendikleri risk paylaşımı yanında meslek veya geçimlerine ait ihtiyaçlarını karşılama imkânına da kavuşmaktadırlar. Dolayısı ile tarafların kooperatif için ortaya koydukları her şeyi teberru olarak değerlendirmek mümkün değildir. Karşılıklı risk dağılımı içinde taraflar menfaatlerini elde etmektedir.

Garanti vermek ve garanti almak bir menfaat olarak değerlendirildiğinde aslında katılımcıların tamamı güvenceye kavuştukları için bu menfaatten faydalanmaktadır. Kooperatif, risk paylaşımını da içeren bir sözleşme statüsünde olduğu ve sözleşmenin tarafları bunu başlangıçta kabul ettiği için sözleşmenin imzalanması ile birlikte tarafların karşılıklı borçlarının doğduğunu düşünebiliriz.

Karşılıklı bedelleri, örnek bir kooperatif ortağı üzerinden aşağıdaki şekilde gösterebiliriz.

Kooperatif ortağı:

- Yardımlaşarak belirli bir emek, iş gücü ortaya koyar,

- Sözleşme gereği belirli bir parasal katkı sunar,

- Zarar oluştuğunda payı oranında kefildir.

- "Olumsuz gelir gider farkı" için payına düşen hesap edilerek kedisine yapılacak iadeden düşülür.

Bu verdiklerine karşılık olarak:

- Meslek ve geçimlerine ait ihtiyaçlarını karşılar,

- Emeği nispetinde bir ölçüye göre olumlu gelir-gider farkı alabilir, ortak dışı işlem yapıldığında ${ }^{95}$ elde edilen kârdan sermaye payları oranında alabilme imkânı vardır,

- Kooperatifin işletme konusu ile ilgili işlerde daha uygun şartlarda ihtiyaçlarını karşılar (üretim, tüketim, işletme, vd.)

95 Üstün/Aydın, s. 455-457. 
Buna göre kooperatifteki mübadele bir miktar parasal katkı ve emek katkısı ile kooperatif himâyesi (zararın telafisi) anlamındaki damân arasında görülebilir. Bu açıdan sigorta ile benzeştiği görülmektedir. Günümüz sigorta hukukunda (TTK, md. 1401-1520) sigorta akdinde mübadele edilen şeylerin, prim ile sigorta himâyesi (sigorta tazminatı) olduğu kabul edilmektedir ${ }^{96}$ Kooperatifte ise ortak; verdiği parasal katkı, emek ve kefillik karşılığında belirli ekonomik menfaatleri, meslek veya geçimine ait ihtiyaçlarını almayı ve kooperatifin himayesini beklemektedir.

İslam âleminde kooperatiflerle ilgili tartı̧̧malar çoğunlukla "sigorta kooperatifleri” üzerinden yürütülmüştür. Yardımlaşmaya dayalı bir yapıda ve tam bir karşılıklı kefillik söz konusu olduğu için ortakların verdiği katkılar "teberru" olarak değerlendirilip cevaz verme yoluna gidilmiştir. ${ }^{97}$ Ancak bu yorum yukarıda ifade edildiği üzere pratik uygulamadaki durum ile örtüşmemektedir.

Kooperatif ortaklarının akitten kaynaklanan sorumlulukların yerine getirme yükümlülüğ̈̈ (bağlayıcılık) açısından incelendiğinde; sözleşmenin taraflarını karşılıklı mükellefiyet altına sokan, yazılı irade beyanı ile kurulan, ivazlı bir sözleşme olması sebebiyle bağlayıcıdır. Zira taraflar bağlayıcılığını kabul ederek yazılı rıza beyanında bulunmuşlardır. İslam hukukunun iki temel kaynağı (Kitap ve Sünnet) tarafların hür iradeleri ile kabul üzere kurulan sözleşmelere riayet etmeyi emreder. Kur’ân'da “Ey iman edenler, sözleşmelerinizi yerine getirin" ${ }^{98}$ buyrulmaktadır. Hz. Peygamber (sav) de "Müslümanlar şartlarına bağlıdırlar" hadisi ile sözleşmenin şartlarına riayet edilmesi emredilmektedir. Mecelle-i Ahkam-1 Adliyye bu emri "bi-kaderi'l-

96 Hacak (2006), s. 40; Günay, Barış (2020), Sigorta Hukuku, 2. Baskı, Ankara, Seçkin s. 5455.

97 Dalgin (2009), s. 163.

98 Mâide, 5/1.

99 Buhâri, “İcâre”, 14; Ebû Dâvûd Süleyman b. Eş’as es-Sicistânî (1981), es-Sünen, İstanbul, Çağrı, "Kazâ", 12; Tirmizî, Muhammed b. İsa b. Serve b. Musâ (1992), es-Sünen, İstanbul, Çağrı, “Ahkâm”, 17. 
imkân şarta mürâat olunmak lâzım gelir” şeklinde ilke haline getirerek "hukuken muteber olan şart" "n gözetilmesi gereğine dikkat çekmiştir. ${ }^{100}$

İslam hukuku akit teorisi açısından bakıldığında "şirket akdinin bağlayıcı olmadığı” yönünde görüşler ${ }^{101}$ olmakla birlikte taraflar için muâvazalı bir akit konumunda değerlendirdiğimiz kooperatif şirketinin bağlayıcı olduğu görüşünü tercih ediyoruz. Zira taraflar karşılıklı sorumluluk altına sokan bir sözleşme söz konusudur. Kooperatifte taraflar, birbirlerine karşı belirli mükellefiyetleri şart koşarak bir sözleşme yapmaktadırlar.

\section{KOOPERATIF, TEKÂFÜL VE KONVANSIYYONEL SIGGORTA FARKI}

Tekâfül, belirli risklerle karşı karşıya kalan kişilerin bu riskler gerçekleşmesi halinde ortaya çıacak zararın tazmin edilmesi üzerine yapılan bir anlaşmadır. İşleyişinde tekâfül sigortalı kişiler teberru mükellefiyeti ile katkı payı öderler. Tekâfül sigortalılarının karşılaştıkları riskler (zararlar) bu teberru fonundan karşılanır. Bu fonun yönetimi sigortalılar arasından seçilen bir kurul ya da ücret karşıllı̆̆ iş ve işlemleri yapan bir anonim şirket tarafından gerçekleştirilir. ${ }^{102}$ Kooperatif ise yukarıda açıklandığı üzere ivazlı bir sözleşmedir ve katılımcılar tam bir karşılıklılık içinde riskleri paylaşırlar. Yönetim de kooperatif ortakları arasından seçilen bir kurul tarafından gerçekleştirilir.

Konvansiyonel sigorta, sigorta işleminden kazanç sağlamayı amaçlayan ivazlı bir sözleşmedir (TTK, md. 1401) ve bir sigorta şirketi üzerinden sigortalıların karşılaştıkları riskler (zararlar) şirket tarafından karşılandıktan sonra artan kısım şirket kârı olarak değerlendirilir. ${ }^{103}$ Ayrıca kooperatifte var

\footnotetext{
100 Mecelle, md. 83.

101 Bu konuda bk. Ceylan, Hadi (2017), "İslâm Borçlar Hukukunda Akdin Bağlayıcılığı" (Doktora), Ankara Üniversitesi Sosyal Bilimler Enstitüsü, 187-188; Ceylan, Hadi (2018), "İslâm Borçlar Hukukunda Akdin Bağlayıcılığının (Lüzûm) Mahiyeti”, Şırnak Üniversitesi İlahiyat Fakültesi Dergisi, C: 9, S: 19, s. 201-215.

102 AAOIFI, s. 666.

103 TTK, md. 1263; AAOIFI, AAOIFI, s. 666-685; Seyyid Muhammed Takiyyü'l-Hakîm, s. 279.
} 
olan karşılıklı yardım ve iş gücü-emek paylaşımı da yoktur. Yönetim şirket tarafından sağlanır ve sigortalı kişilerin katılımı söz konusu değildir. ${ }^{104}$ Kooperatiflerde ise paydaşlardan birinin belirli bir rizikonun gerçekleşmesi halinde doğacak zararını tazmini içeren karşılıklı bir sigorta söz konusudur (TTK, md. 1402) ve şirketi ortaklar yönetir.

Netice olarak zararın tazmin edilmesi konusu; kooperatif, tekâfül ve konvansiyonel sigortada ortak payda olmakla beraber her üç ortaklık da içlem ve kaplam olarak birbirlerinden farklı özelliklere sahiptir.

\section{HUKUKİ DÜZENLEMLERINNDE İSLAM HUKUKUNDAN ESINLENEN ÜLKELERDE KOOPERATİF İLE İLGILİ DÜZENLEME ve PRATÍKLER}

Konumuza ışık tutması bakımından, ülke isminin başında "İslam" nitelemesi buluna ya da hukuk kurallarını düzenlerken İslam hukuku esaslarından faydalanmaya çalışan Müslüman ülkelerden bazılarının kooperatif ile ilgili hukuki düzenleme ve pratiklerini özetle aşağıdaki şekilde ifade edebiliriz.

Suudi Arabistan'da kooperatif ile ilgili yasal düzenleme 1962 yılında yapılmıştır. ${ }^{105}$ Suudi Arabistan Kooperatif Toplulukları Konseyi ise 2008 yılında kurulmuş olup ${ }^{106}$ günümüzde Çalışma ve Sosyal Kalkınma Bakanlığına bağlı olarak 233 kooperatif birliği, faaliyet göstermektedir. ${ }^{107}$

İran İslam Cumhuriyetinde 1979 Devrimi'nden sonra kooperatif ülke Anayasasında yerini almış olup kooperatif işlerinin yürütülmesi ve

\footnotetext{
104 AAOIFI, s. 666.

105 International Labour Organization (ILO) "Saudi Arabia", https://www.ilo.org/dyn/natlex/natlex4.detail?p_lang=en\&p_isn=32330\&p_country=SAU\& p_count $=88 \&$ p_classification $=11 \&$ p_classcount $=2$ s.e.t. 08.12 .2020 .

106 International Co-operative Alliance Asia-Pacific (ICA), "Saudi Arabia", http://icaap.coop/AboutUs/co-operative-societies-councilcsc\#: :text=Cooperative\%20Societies\%20Council\%20(CSC)\%20has, and\%20technical\%20ca pabilities\%2C\%20and\%20establish> s.e.t. 08.12.2020.

107 Saudi Gazette "233 cooperative societies all over KSA", <https://saudigazette.com.sa/article/544098> s.e.t. 08.12.2020.
} 
denetlenmesinden sorumlu olarak "Kooperatifler Bakanlı̆̆ı" 1991 yılında kurulmuştur. ${ }^{108}$ Daha sonra bu bakanlık 2011 yılında Çalışma Bakanlığı ve Sosyal Güvenlik Bakanlığı ile birleştirilmiş ve halen "Kooperatif, Çalışma ve Sosyal Güvenlik Bakanlığı” adı altında görevini devam ettirmektedir. ${ }^{109}$ İran ekonomisinde 120'den fazla sektör ve alt sektörlerinde 93 binden fazla kooperatif sayısı 9,5 milyondan fazla üye sayısı ile ülke nüfusun yaklaşık $\% 12$ 'si bir kooperatife üyedir. ${ }^{110}$

Malezya'ya kooperatif ile ilk defa 1922 yllında İngiliz sömürge hâkimiyeti zamanında tanışmıştır. ${ }^{111}$ Zamanla gelişerek 1971'de Angkatan Kerjasama Kebangsaan Malaysia Berhad (ANGKASA) resmen "ulusal birlik" olarak tescil edilmiş, sonraki yıllarda Malezya'da birleşik ve zorlu bir kooperatif hareketi başlamıştır. 1993 yılında yeni Kooperatif Yasası'nın onaylanmasıyla ANGKASA, ulusal ve uluslararası kooperatif hareketini temsil etmesi için Malezya hükümeti tarafından resmen tanınmıştır. İslami kooperatiflerle ilgili yapılan ana düzenleme 1993 yılında başlamış olup daha sonra 2007 yılında ve 2016 yılında değişiklikler yapılmış olmasına rağmen tamamen İslam hukukuna uygun olarak da yorumlanmamaktadır. ${ }^{112} 2019$

108 Iran Chamber of Cooperatives "Iran", <https://www.icccoop.ir/Iran-ICC> s.e.t. 08.12.2020.

International Labour Organization (ILO) “Act on Cooperative Sector of Economy of the Islamic Republic of Iran (with Amendments), <https://www.ilo.org/dyn/natlex/docs/MONOGRAPH/91867/119814/F577166946/IRN918 67\%20Eng.pdf> s.e.t. 08.12.2020.

110 International Co-operative Alliance Asia-Pacific (ICA) "Cooperatives in Iran, <http://icaap.coop/sites/ica-ap.coop/files/2020\%20Iran\%20Country\%20Snapshot_0.pdf> s.e.t. 08.12.2020.

111 International Co-operative Alliance Asia-Pacific (ICA) "The Malaysian Co-operative Movement", <https://www.ica.coop/en/malaysian-co-operative-movement\#: :text= Formation\%20of\%20Angkasa,establish\%20a\%20national\%20cooperative\%20union.\&text= With\%20the\%20approval\%20of\%20the,operative\%20movement\%20nationally\%20and\%20i nternationally>08.12.2020.

112 Issyam, Muhammad/ Hasan, Rusni bt/ Alhabshi, Syed Musa (2016), "Shariah Governance Framework For Islamic Co-Operatives As An Integral Social Insitution In Malaysia”, Intellectual Discourse, <https://journals.iium.edu.my/intdiscourse /index.php/id/article/view/930/676> s.e.t. 08.12.2020. 
verilerine göre 14 binden fazla kooperatif sayısı, 6 milyondan fazla üye sayısı ve 5,95 milyar ABD Doları yıllık cirosu ile gelişimini devam ettirmektedir. ${ }^{113}$

Endonezya'da kooperatif ile ilk defa 1896'da Hollanda sömürge hâkimiyeti zamanında tanışmıştır. 1945'te Endonezya anayasasına girmiş, 1947'de Endonezya Kooperatif Konseyi (DEKOPIN) kurulmuştur. Kooperatiflere dair işlemler ve denetimler 1992 yllında kabul edilen yasaya göre yapılmaktadır. ${ }^{114} 212$ binden fazla kayıtlı kooperatifi bulunan Enonzya'da ülke nüfusunun yaklaşık \% 15'i bir kooperatife üyedir. ${ }^{115}$

Pakistan da Malezya ve Endonezya'da olduğu gibi kooperatif hareketi ile sömürge hâkimiyeti döneminde tanışmış olup kooperatiflere temel teşkil eden hukuki düzenleme 1925 yılındaki "kooperatif Birlikleri Yasası" ile yapılmıştır. Ülke 1947 yılında özgürlüğünü kazandıktan sonra bu alandaki düzenlemeler eyaletlere (Pencap, Sind, vd.) göre farklı içeriklerle gelişerek devam etmiştir. ${ }^{116}$ Günümüzde Pakistan'da 8 binden fazla kooperatif ve 26 milyondan fazla kooperatif üyesi vardır. ${ }^{117}$

113 International Co-operative Alliance Asia-Pacific (ICA) "Cooperatives in Malaysia" $<$ https://icaap.coop/sites/ica-ap.coop/files/2019\%20Malaysia\%20country\%20snapshot.pdf> s.e.t. 08.12 .2020 .

114 International Labour Organization (ILO) "Statistics on Cooperatives Country in Focus: Indonesia", <https://www.ilo.org/wcmsp5/groups/public/---ed_emp/---emp_ent/--coop/documents/publication/wcms_626174.pdf> s.e.t. 08.12.2020.

115 Azhari/ Syechalad, Mohd Nur/ Hasan, Ishak/ Abd. Majid, M. Shabri, "The Role of Cooperative in the Indonesian Economy", International Journal of Humanities and Social Science Invention,

$<$ https://www.researchgate.net/profile/M_Shabri_Abd_Majid/publication/322143870_The_ Role_of_Cooperative_in_the_Indonesian_Economy/links/5d586b11a6fdccb7dc457278/The -Role-of-Cooperative-in-the-Indonesian-Economy.pdf> s.e.t. 08.12.2020.

116 Cooperation Department Geverment of Sindh "Introduction of Department", $<$ https://sindh.gov.pk/dpt/Cooperation/index.htm> s.e.t. 08.12.2020; Cooperatives Department Goverment of The Punjab "Legal Framework", $<$ https://cooperatives.punjab.gov.pk/legal_framework> s.e.t. 08.12.2020.

117 Cooperative Housing International (CHI) "The Co-operative Housing Movement", https://www.housinginternational.coop/co-ops/pakistan/ 
Yukarıda örneklerini verdiğimiz Müslüman ülkelerin tamamında Batı ülkelerinde ortaya çıkan kooperatif hareketinden etkilenerek hukuki düzenleme ve pratik yaptıkları gözlemlenmektedir.

\section{SONUÇ}

Kooperatiflerin tarihi arka planı, gelişimi ve işleyişi incelendiğinde toplumların dayanışma ve risk paylaşımı ihtiyacından neşet ettikleri görülmektedir. Her toplum kendi siyasi yönetim anlayışına göre hukuki düzenlemeler yaparak kooperatif şirketlerine yer vermiştir. Ancak dünyada uygulama alanı bulan bütün kooperatiflerde ortak hareket noktasının, aynı amaç birliği içinde yer alan kişilerin birbirleri ile yardımlaşmak, dayanışmak ve karşıllklı kefalet amacı çerçevesinde yaptıkları bir sözleşme ile bir araya gelmesi olduğu söylenebilir.

Hukukta ticari ya da sosyal bir topluluğun yerinin belirlenmesi ortaya çıkacak uyuşmazlıkların çözümünde büyük önem arz etmektedir. Kuruluşların kendilerine özel yasa ve statüleri ile tüm problemlere çözüm bulmak her zaman mümkün olmayabilir. Ortaklık hakkındaki meselelerin çözümlerinde önce özel hükümler ve her türlü ortaklık çeşidi için genel hükümler, nihayet öğreti ve Yargıtay kararları ile de uyumlu olan ilkeler belirlenmiştir.

Kooperatiflerin hukuki niteliği günümüz hukukçuları arasında tartışma konusu olmuştur. Hem şirket özellikleri göstermesi hem de dernek ve sendikalar gibi kâr amacı gütmeyen dayanışma örgütlerinin özelliklerini göstermesi bakımından kooperatifler kendine has özellikleri olan (sui generis) bir birlik yapısı olarak nitelendirilmiştir. Türk hukuk mevzuatında şahıs şirketleri ve sermaye şirketleri içinde sayılmayan kooperatifler kendine has özellikleri göz önünde bulundurularak ticari şirketler içinde sayılmıştır.

İslam hukuku açısından kooperatifler; kendine has yapısı olan (sui generis), isimsiz, ivazlı sözleşme kapsamında kurulan bir akit şirketi olarak nitelendirilebilir. İslam hukukuna göre; Kooperatifler Kanununda tanımlandığı şekliyle bir anasözleşme çerçevesinde ortaklar ve kooperatifin birbiriyle karşılıklı yardımlaşma, dayanışma ve kefaleti esasına dayanan; kural olarak serbest katılım ve çıkma imkânı olan; kişi unsuru birinci sırada, pay ikinci sırada olan; unvanında "kooperatif” sözcüğünün bulunma zorunluluğu 
bulunan; sermayenin zorunlu bir unsur olmayıp araç niteliğinde bulunduğu; ortakların yaptıkları katkı payına ve sermaye katılım payına bakılmaksızın yönetimde her ortağın sadece bir oy hakkının olduğu mutlak eşitlik ve ortakların kooperatifle olan ilişkisi nispetinde, farklı durumları göz önüne alınarak belirli bir ölçüye göre menfaat elde edebildiği nisbi eşitlik özelliklerini haiz bir tüzel kişilik olarak kooperatif ortaklığı kurmak mümkündür. Kooperatifler kanunundaki şeklinin dışında aynı ilkeleri benimseyerek bu ortaklık, unvanda "kooperatif” sözcüğü zorunluluğu olmadan da kurulabilir. Ancak bu ortaklıklara dair oluşturulan anasözleşme özellikle garar, riba, cehâlet, kumar gibi özellikleri taşımayacak şekilde kurgulanmalı ve İslam akit teorisi kapsamındaki sabit ilke, hüküm ve değerlerle örtüşmelidir. 


\section{KAYNAKÇA}

AAOIFI, The Accounting and Auditing Organization for Islamic Financial Institutions Shari'ah Standards (2015), Bahryen, Dar AlMaiman (Çeviren: Sabahattin Zaim Üniversitesi (2018), Faizsiz Finans Kuruluşları Muhasebe ve Denetleme Kurumu Faizsiz Finans Standartları 2015, İstanbul, TKBB).

Ahmet Cevdet Paşa (1985), Açıklamalı Mecelle, (Metin ve Açıklamaları Kontrol Eden: Ali Himmet Berki), İstanbul, Hikmet.

Aktan, Hamza (1989), “Âkıle”, Türkiye Diyanet Vakfı İslam Ansiklopedisi, İstanbul, TDV, C: 2, s. 248-249.

Ayhan, Rıza/Çağlar, Hayrettin/Özdamar, Mehmet (2020), Şirketler Hukuku Genel Esaslar. Ankara: Seçkin yayınları, 2. Baskı.

Azhari/ Syechalad, Mohd Nur/ Hasan, Ishak/ Abd. Majid, M. Shabri, "The Role of Cooperative in the Indonesian Economy", International Journal of Humanities and Social Science Invention, $<$ https://www.researchgate.net/profile/M_Shabri_Abd_Majid/publicati on/322143870_The_Role_of_Cooperative_in_the_Indonesian_Econom y/links/5d586b11a6fdccb7dc457278/The-Role-of-Cooperative-in-theIndonesian-Economy.pdf> s.e.t. 08.12.2020.

Bayyiğit, Mehmet (Editör) (1997), 1. Uluslararası İslâm Ticaret Hukukunun Günümüzdeki Meseleleri Kongresi - 1996, "Sigorta Sonuç Bildirisi", $<$ http://www.islamticarethukuku.org/pageflip/magazine.php?no=6> s.e.t. 10.08 .2020 .

Bayyiğit, Mehmet (Editör) (2016), 2. Uluslararası İslâm Ticaret Hukukunun Günümüzdeki Meseleleri Kongresi - 2015, "Sigorta Sonuç Bildirisi”, < http://www.islamticarethukuku.org/sigorta-oturumu-sonuc-bildirisi70h.htm> s.e.t. 10.08.2020.

Beşer, Faruk (1988), İslam'da Sosyal Güvenlik, İstanbul, Sehâ Neşriyat, 1988.

Bilgin, Necdet/Şaban, Tanıyıcı (2008), “Türkiye'de Kooperatif Ve Devlet İlişkilerinin Tarihi Gelişimi”.Karamanoğlu Mehmetbey Üniversitesi İİF Dergisi, C: 10, S: 15, s. 136-159. 
Bilmen, Ömer Nasuhi (t.y.), Hukukı İslamiyye ve Istılahatı Fıkhiyye Kamusu, İstanbul, Bilmen.

Buhârî, Ebu Abdillah Muhammed b. İsmail (1992) el-Câmiu's-Sahîh, İstanbul, Çağrı.

Ceylan, Hadi (2017), "İslâm Borçlar Hukukunda Akdin Bağlayıcılığı" (Doktora), Ankara Üniversitesi Sosyal Bilimler Enstitüsü.

Ceylan, Hadi (2018), "İslâm Borçlar Hukukunda Akdin Bağlayıcıllğının (Lüzûm) Mahiyeti”, Şırnak Üniversitesi İlahiyat Fakültesi Dergisi, C: 9, S: 19, s. 201-215.

Cooperation Department Geverment of Sindh "Introduction of Department", <https://sindh.gov.pk/dpt/Cooperation/index.htm> s.e.t. 08.12.2020.

Cooperative Housing International (CHI) "The Co-operative Housing Movement", https://www.housinginternational.coop/co-ops/pakistan.

Cooperatives Department Goverment of The Punjab "Legal Framework", $<$ https://cooperatives.punjab.gov.pk/legal_framework> s.e.t. 08.12.2020.

Çalış, Halit (2004), "İslâm Borçlar Hukukunda Akit Serbestisi ve Genel Olarak Sınırlamaları", Dini Araştırmalar, C: 7, S: 19 s. 269-295.

Dalgın, Nihat (1997) "Kaza, Hayat ve İşsizlik Sigortalarına Yeni Bir Yaklaşım”: Mehmet Bayyiğit (Editör), 1. Uluslararası İslâm Ticaret Hukukunun Günümüzdeki Meseleleri Kongresi, Konya, Kombad, s. 878-928.

Dalgın, Nihat (2009) “Sigorta", Türkiye Diyanet Vakfı İslam Ansiklopedisi, İstanbul, TDV Yayınları, C:37, s. 159-164.

Dalkıran, Gülüm Burcu (2017), “The Support of Women Work within Cooperative Enterprises: Sample of Turkey”, Social Sciences Research Journal, C: 6, S: 3, s. 1-11.

Dönmez, İbrahim Kâfi (2010), "Şahıs", Türkiye Diyanet Vakfı İslam Ansiklopedisi, İstanbul, TDV, C: 38, s. 270-273.

Ebu Ceyb, Sadi (1988), el-Kâmûsu'l-Fıkhiyye, Dimeşk, Dâru'l-Fikr.

Ebû Dâvûd Süleyman b. Eş'as es-Sicistânî (1981), es-Sünen, İstanbul, Çağrı. 
Erdoğan, Mehmet (1998), Fıkıh ve Hukuk Terimleri Sözlüğü, İstanbul, Rağbet.

Göç Gürbüz, Diğdem (2010), "Kooperatiflerde Ortakların Sorumluluğu”, Marmara Üniversitesi İIBBF Dergisi, C: 28, S: 1, s. 463-477.

Gözübenli, Beşir (2010), "Şirket”, Türkiye Diyanet Vakfı İslam Ansiklopedisi, İstanbul, TDV, C:39, s. 198-201.

Günay, Barış (2020), Sigorta Hukuku, 2. Baskı, Ankara, Seçkin.

Habergetiren, Ömer Faruk (2005), “İslam Hukuku'nda Sermaye ve Sermaye Hareketleri” (Doktora) Harran Üniversitesi Sosyal Bilimler Enstitüsü.

Hacak, Hasan (2006), "İslâm Hukukunda Sigorta ve Fıkıh Bilginlerinin Sigortaya Yaklaşımının Genel Bir Değerlendirmesi”, M.Ü. İlâhiyat Fakültesi Dergisi. C: 30, S: 1, s. 21-50.

Hacak, Hasan (2016), "İslam Hukukunun İlkeleri Açısından Alacak (Kredi) Sigortası": Mehmet Bayyiğit (Editör), 2. Uluslararası İslâm Ticaret Hukukunun Günümüzdeki Meseleleri Kongresi, Konya, KTO Karatay Üniversitesi, s. 1011-1038.

Haçkalı, Abdurrahman (2002), "İslam Hukuku Açısından Akit Serbestisi Prensibi”, Dini Araştırmalar, C: 5, s. 13, 119-136.

Hançerlioğlu, Orhan (1993), Ekonomi Sözlügü. 5. Baskı. İstanbul, Remzi.

Hony, H. H. C./İz, Fahir (1992), The Oxford Turkish English Dictionary, 3. Baskı. Türkiye, İnkılâp/Oxford UniversityPress.

International Cooperative Alliance (ICA), "History of the cooperative movement", <https://www.ica.coop/en/history-co-operativemovement> s.e.t. 20.08.2020.

International Co-operative Alliance Asia-Pacific (ICA) "Cooperatives in Iran", $<\mathrm{http}$ ://icaap.coop/sites/icaap.coop/files/2020\%20Iran\%20Country\%20Snapshot_0.pdf> s.e.t. 08.12.2020.

International Co-operative Alliance Asia-Pacific (ICA) "Cooperatives in Malaysia" $<$ https://icaap.coop/sites/icaap.coop/files/2019\%20Malaysia\%20country\%20snapshot.pdf> s.e.t. 08.12.2020. 
International Co-operative Alliance Asia-Pacific (ICA) "The Malaysian Cooperative Movement”, <https://www.ica.coop/en/malaysian-cooperative-movement\#: :text=Formation $\% 20$ of $\% 20$ Angkasa,establish $\% 20 \mathrm{a} \% 20$ national\%20cooperative\%20union.\&text=With\%20the\%20ap proval $\% 20$ of $\% 20$ the,operative $\% 20$ movement $\% 20$ nationally $\% 20$ and $\% 20$ internationally $>08.12 .2020$.

International Co-operative Alliance Asia-Pacific (ICA), "Saudi Arabia", http://icaap.coop/AboutUs/co-operative-societies-councilcsc\#: :text=Cooperative\%20Societies\%20Council\%20(CSC)\%20has, and $\% 20$ technical\%20capabilities\%2C\%20and\%20establish> s.e.t. 08.12.2020.

International Cooperative Alliance, "Cooperative identity, values \& principles”, <https:/www.ica.coop/en/cooperatives/cooperativeidentity> s.e.t. 20.08.2020.

International Labour Organization (ILO) "Act on Cooperative Sector of Economy of the Islamic Republic of Iran (with Amendments), $<$ https://www.ilo.org/dyn/natlex/docs/MONOGRAPH/91867/119814/F 577166946/IRN91867\%20Eng.pdf> s.e.t. 08.12.2020.

International Labour Organization (ILO) "Saudi Arabia", https://www.ilo.org/dyn/natlex/natlex4.detail?p_lang=en\&p_isn=32330 \&p_country=SAU\&p_count $=88 \&$ p_classification $=11 \&$ p_classcount $=2$ s.e.t. 08.12 .2020 .

International Labour Organization (ILO) "Statistics on Cooperatives Country in Focus: Indonesia", <https://www.ilo.org/wcmsp5/groups /public/---ed_emp/---emp_ent/---coop/documents/publication/ wcms_626174.pdf> s.e.t. 08.12.2020.

Iran Chamber of Cooperatives "Iran", <https://www.icccoop.ir/Iran-ICC> s.e.t. 08.12 .2020 .

Issyam, Muhammad/ Hasan, Rusni bt/ Alhabshi, Syed Musa (2016), "Shariah Governance Framework For Islamic Co-Operatives As An Integral Social Insitution In Malaysia", Intellectual Discourse, $<$ https://journals.iium.edu.my/intdiscourse/index.php/id/article/view/9 30/676> s.e.t. 08.12 .2020 . 
İbn Âbidin, Muhammed Emîn b. Ömer b. Abdilazîz (1325), Mecmûatu'rResâil, İstanbul, Şirket-i Sahafiye-i Osmaniye.

İbn Âbidin, Muhammed Emîn b. Ömer b. Abdilazîz (1995), Reddu'lMuhtâr, Beyrut, Dâru'l-Fikr.

İbn Kudâme, Ebu Muhammed Muvaffakuddin Abdullah b. Ahmed b. Muhammed (1992), el-Muğni, Beyrut, Dâru'l-Fikr.

İbn Mâce, Ebû Abdillah Muhammed b. Yezid el-Kazvînî (1981), es-Sünen, Çağrı.

İbn Manzûr, Ebu'l-Fazl Cemaluddin Muhammed b. Mukerrem (1990), Lisanu'l-Arab, Beyrut, Daru Sadır.

Kahraman, Abdullah (2008), İslam Borçlar Hukukunda Kefâlet Sözleşmesi ve Günümüzdeki Tatbikatı, İstanbul, M.Ü. İlahiyat Fakültesi Vakfı.

Kallek, Cengiz (2000) "İhtikâr”, Türkiye Diyanet Vakfı İslam Ansiklopedisi, C: 21 , s. 560-565.

Karâfî, Ebü'l-Abbâs Şihâbüddîn Ahmed b. İdrîs b. Abdirrahmân el-Misrî (2010), Envârü'l-Burûk fî Envâ' i'l-Furûk, Kuveyt, Dâru'n-Nevâdir.

Karaman, Hayrettin (1992), İslam’a Göre Banka ve Sigorta, İstanbul, Nesil.

Karaman, Hayrettin (2012), İş ve Ticaret İlmihali, İstanbul, İz.

Karaman, Hayrettin (2013), Mukayeseli İslam Hukuku, İstanbul, İz.

Karaman, Hayrettin/Özdemir, Ahmet (2019), Fıkhi Bilgi ve İlişkiler Işı̆̆ında Eşya ve Şahsın Hukuku, İstanbul, Kitabi.

Kelebek, Mustafa (2015), İslam Vakıf Hukuku ve Sivas Dâru'ş-Şifâ Vakfiyesi, İstanbul, Ravza.

Kizılaslan, Halil/Menek, Mehmet (2011), “Türkiye'de Kooperatiflerin Hukuki Statüsü ve Vergiler Karşısındaki Durumu”, ZKÜ Sosyal Bilimler Dergisi, C: 7, S: 13, s. 37-52.

Konya Şeker, “Türkiye'nin Üreten Gücü”, $<$ http://www.konyaseker.com.tr/tr/icerik/detay/2113/konya-seker > s.e.t. 20.08.2020.

Kooperatifler Kanunu (Koop.K), Resmî Gazete 13195 (10 Mayıs 1969), Kanun No: 1163, <https://www.mevzuat.gov.tr/mevzuat?MevzuatNo= $1163 \&$ MevzuatTur=1\&MevzuatTertip=5> s.e.t 20.07.2020. 
Kooperatifler Kanununda Değişiklik Yapılması Hakkında Kanun (Koop.KDK) Resmî Gazete 25455 (7 Mayıs 2004), Kanun No: 5146, <https://www.resmigazete.gov.tr/eskiler/2004/05/20040507.htm\#1> s.e.t 20.07.2020.

Köse, Murtaza (1998), "İslam Hukuku Ve Modern Hukuka Göre Tüzel Kişilik”, Ekev Akademi Dergisi, C: 1, S: 2, s. 221-230.

Kudûrî, Ahmed b. Muhammed (2018), el-Kitâb Muhtasaru'l-Kudûrî Fi'lFikhi'l-Hanefî, Konya, Burç.

Kurt, İsmail (2020), "Şer'î Açıdan Vakıf ve Vakıfların Muhasebe Usulü”, İSAV, <http://www.isav.org.tr/img/20131029_506250263.pdf > s.e.t. 15.08.2020.

Merginânî, Ebï'l-Hasen Burhânüddîn Alî b. Ebî Bekr b. Abdilcelîl elFergānî (t.y.), el-Hidâye, İstanbul, Eda.

Mollaoğlu, Yusuf (2018) “Kooperatiflerin Hukuki Niteliği” (Yüsek Lisans), Selçuk Üniversitesi, Sosyal Bilimler Enstitüsü.

Mülayim, Ziya Gökalp (2012), "Kooperatif Kuruluşlarda Üst Örgütlenmenin Önemi ve Türkiye'de Sorunları", İstanbul Üniversitesi, Sosyal Siyaset Konferansları Dergisi, S: 40, s. 33-42.

Müslim, Ebu'l-Huseyin Müslim b. Haccâc (1981), el-Câmiu's-Sahîh, İstanbul, Çağrı.

Nesâî, Ebû Abdurrahman Ahmed b. Şuayb b. Ali b. Bahr b. Sinan b. Dinâr (1981), Sünen-i Nesâî, İstanbul, Çağrı.

Poroy, Reha (1991), Ticari İşletme Hukuku, 6. Baskı, İstanbul, Beta.

Poroy, Reha/Tekinalp, Ünal/Çamoğlu, Ersin (2005) Ortaklıklar ve Kooperatif Hukuku, İstanbul, Arıkan.

Poroy, Reha/Tekinalp, Ünal/Çamoğlu, Ersin (2010) Ortaklıklar ve Kooperatif Hukuku, 12. Baskı, İstanbul, Vedat Kitapçlık.

Poroy, Reha/Tekinalp, Ünal/Çamoğlu, Ersin (2017) Ortaklıklar Hukuku II, 13. Baskı, İstanbul, Vedat Kitapçıllk.

Saudi Gazette "233 cooperative societies all over KSA", $<$ https://saudigazette.com.sa/article/544098> s.e.t. 08.12.2020. 
Serahsî, Ebû Bekr Şemsü'l-Eimme Muhammed b. Ebî Sehl Ahmed (1989), el-Mebsût, Beyrut, Dâru'l-Fikr.

Seyidoğlu, Halil (1992), Ekonomik Terimler Ansiklopedik Sözlük, Ankara, Güzem.

Seyyid Muhammed Takiyyü'l-Hakîm, Abdu'l-Hâdî (2010) Akdü't-Te'mîn. Hakîkatuhû ve Meşrû'iyyetehû, Beyrut, Menşûrâtu'l-Halebiyyi'lHukukiyye.

Şener, Oruç Hami (2019) Teorik ve Uygulamalı Ortaklar Hukuku, Ankara, Seçkin.

T.C. Adalet Bakanlı̆̆ı Hukuk Sözlüğ̈̈, “Tacir” $<$ https://sozluk. adalet.gov.tr/tacir> s.e.t. 20.08.2020.

T.C. Ticaret Bakanlığı, “Denetim İşlemleri”, <https://www.ticaret. gov.tr/kooperatifcilik/kooperatiflere-yonelik-hizmetler/denetimislemleri> s.e.t. 20.07.2020.

T.C. Ticaret Bakanlı̆̆ı, "Kooperatif Nasıl Kurulur?", <https://ticaret. gov.tr/kooperatifcilik/kooperatif-nasil-kurulur> s.e.t. 20.07.2020.

T.C. Ticaret Bakanlığı, "Kooperatifçilik İlkeleri”, <https://ticaret.gov.tr/ kooperatifcilik/kooperatifler-hakkinda-bilgiler/kooperatifcilik-ilkeleri> s.e.t. 20.07.2020

T.C. Ticaret Bakanlığı, "kooperatifçilik İlkeleri”, <https://ticaret.gov.tr/ kooperatifcilik/kooperatifler-hakkinda-bilgiler/kooperatifcilik-ilkeleri $>$ s.e.c. 17.07.2020.

T.C. Ticaret Bakanlığı, “Tarihçe, Türkiye'de Kooperatifçilik”, <https:// ticaret.gov.tr/kooperatifcilik/kooperatifler-hakkinda-bilgiler/tarihce> s.e.t. 17.07.2020.

T.C. Ticaret Bakanlığı, “Türkiye'de Kooperatifçilik”, <https:// ticaret.gov.tr/kooperatifcilik/bilgi-bankasi/kooperatiflerhakkinda/turkiyede-kooperatifcilik> s.e.t.20.07.2020.

Tirmizî, Muhammed b. İsa b. Serve b. Musâ (1992), es-Sünen, İstanbul, Çağrı.

Topal, Cemre/ Kalaycı, Filiz (2007), Gerekçeli-Notlu Türk Medeni Kanunu, Ankara, Bilge. 
Torku , “Tarihçe”, <http://torku.com.tr/tr/icerik/detay/170/tarihce> s.e.t. 20.08.2020

Torku, "Kooperatifçilik Bizim İçin Seçenek Değil Mecburiyettir", $<$ http://torku.com.tr/tr/haber/detay/10140/kooperatifcilik-bizim-icinsecenek-degil-mecb> s.e.t. 20.08.2020.

Türkiye Kooperatifler Birliği, “Türkiye Milli Kooperatifler Birliği Tarihçesi”, $<$ http://www.turkey.coop/menu/Turkiye-Milli-Kooperatifler-BirligiTarihcesi/11> s.e.t. 18.07.2020.

Udeh, Abdu'l-Kâdir (t.y.), et-Teşrîu'l-Cinâî, Beyrut, Dâru’l-Kâtibi'l-Arabî.

University of California, "What is a Cooperative?" $<$ http://sfp.ucdavis.edu/cooperatives/what_is > s.e.t. 18.07.2020.

Ültanir, Memnune Sıla (2019), “Türkiye'de Kooperatifçiliğin Tarihsel Seyri: Devlet İnisiyatifi-Kalkınma İdeali” (Yüksek Lisans Tezi), Hacettepe Üniversitesi, Sosyal Bilimler Enstitüsü.

Üstün, Yusuf (2014a), "Sigorta, Tekafül ve Kooperatif Sigortacılığı”, Karınca Dergisi, S: 927, s. 3-12.

Üstün, Yusuf (2014b), "Normlar Hiyerarşisi Ve Kooperatiflerin Denetimi Meselesi”, Tematic Ticaret ve Mevzuat Araştırmaları Dergisi, S: 2, s. 110, <https://ticaret.gov.tr/data/5d41e48b13b87639ac9e02df/1794d24757 d0ddfc277bd3ca1fa54a5d.pdf> s.e.t. 20.08.2020.

Üstün, Yusuf/Aydın, Muhittin (2014), Kooperatifler Hukuku, Ankara, Banka ve Ticaret Hukuku Araştırma Enstitüsü.

Yaman, Ahmet/Çalış, Halit (2018), İslam Hukuku, Ankara, Bilay.

Zerkâ, M. Ahmed, (1992) “İslâm’a Göre Sigorta”, (Çeviren: Karaman, Hayrettin), İslam’a Göre Banka ve Sigorta, İstanbul, Nesil Yayınları, s. 203-245.

Zuhaylî, Vehbe (1989), el-Fıkhu'l-İslâmî ve Edilletuhû, Dımeşk, Dâru’l-Fikr. 